Article

\title{
Elemental Geochemical Characterization of Sedimentary Conditions and Organic Matter Enrichment for Lower Cambrian Shale Formations in Northern Guizhou, South China
}

\author{
Shuangbiao Han ${ }^{1,2, *}$, Yuanlong Zhang ${ }^{2,3, *}$, Jie Huang ${ }^{2}$, Yurun Rui ${ }^{2}$ and Zhiyuan Tang ${ }^{2}$ \\ 1 State Key Laboratory of Shale Oil and Gas Enrichment Mechanisms and Effective Development, \\ Beijing 100083, China \\ 2 College of Geoscience and Surveying Engineering, China University of Mining and Technology, \\ Beijing 100083, China; lukehuangjie@163.com (J.H.); r17800834537@163.com (Y.R.); cumtbtzy@163.com (Z.T.) \\ 3 School of Earth and Space Sciences, Peking University, Beijing 100871, China \\ * Correspondence: hans@cumtb.edu.cn (S.H.); zhangyl2020@stu.pku.edu.cn (Y.Z.)
}

Received: 22 August 2020; Accepted: 7 September 2020; Published: 8 September 2020

check for updates

\begin{abstract}
The black shale deposited in the Niutitang Formation and its adjacent strata is considered to be a favorable source rock in northern Guizhou of south China and has become a target horizon for shale gas exploration in recent years. Based on SQ-1 and CY-1 core samples, the organic matter properties and geochemical elements were obtained through experimental analysis. Provenance, paleoredox, paleoclimate, paleoproductivity and deposition conditions were analyzed, and the sedimentary effects on organic matter enrichment were discussed. The results show that total organic carbon (TOC) is between $0.22-10.10 \mathrm{wt}$.\% in SQ-1, with an average of $2.60 \mathrm{wt} . \%$, and TOC is between $0.23-7.7 \mathrm{wt} . \%$ in CY-1, with an average of $1.45 \mathrm{wt}$.\%. The geochemical data of the samples indicate that the black shale of the Niutitang Formation and adjacent strata are deposited in the tectonic background of the passive continental margin. The provenance shows moderate weathering, with hot and humid paleoenvironmental characteristics and fast deposition rate. Using multiple ancient redox indicators, it is concluded that the formation has undergone changes in the oxidizing environment and anaerobic environment during deposition. According to the $(\mathrm{La} / \mathrm{Yb})_{\mathrm{N}}$ value (the average value of SQ-1 is 1.23 and the average value of CY-1 is 1.26), it shows a faster deposition rate of the two wells and shortens the residence time of organic matter in the microbial degradation zone. The Babio indicates that the bottom has a high paleoproductivity when deposited. Considering the influencing factors, the paleoproductivity mainly controls the organic matter enrichment, followed by ancient redox conditions and the deposition rate. The research results provide a reference for deepening sedimentary understanding and shale gas exploration in the study area.
\end{abstract}

Keywords: Niutitang shale formation; geochemical elements characteristics; paleoenvironmental evolution; northern Guizhou

\section{Introduction}

The successful large-scale commercial development of shale gas resources in the USA not only significantly changed the energy structure of the country, but also had an important impact on the world natural gas market, energy structure and geopolitics. Shale gas exploration, development and related research in China started late [1]. In addition to the industrialized development of shale gas fields such as Fuling Jiaoshiba and Changning-Weiyuan, the other regions are still in the initial stage. In the past 10 years, China's shale gas has been successfully commercialized mainly in the Silurian 
Longmaxi shale formation in Sichuan Basin [2-5]. It is noteworthy that the Lower Cambrian Niutitang Formation and its adjacent strata (including the Jiumengchong Formation and the Bianmachong Formation) are very similar to the Longmaxi Formation in lithology, organic matter enrichment degree and thermal evolution [6]. Therefore, a certain extent of exploration and development has also been carried out in south China.

In this study, core samples were obtained from the SQ-1 and CY-1, which were completed in northern Guizhou area, south China. The total organic carbon (TOC), as well as the concentration of main elements, trace elements, and rare earth elements (REE) were analyzed to reveal elemental geochemical characteristics of the Lower Cambrian shale formations; the provenance, paleoclimate, paleoproductivity, paleoxidation conditions of this strata are researched when sedimentation occurred; the deposition conditions' effect on the organic matter enrichment was discussed.

\section{Geological Setting}

The study area is located in the northern part of Guizhou Province, and its structure belongs to the Qiannan depression in the Jiangnan compound orogenic belt. The Late Proterozoic to Cenozoic strata developed in northern Guizhou, and were formed in different sedimentary environments and had different sedimentary combinations (Figure 1). Integrated with the analysis of regional geological data, three sets of great-and-deep faults with different scales and trending roughly NE, SN, and EW, respectively, have controlled the tectonic frame and structural patterns of the study area. The study area is dominated by roughly NE-and S-N-trending lineaments, with the former usually transformed by and restrict the latter, as well as some minor E-W-trending lineaments. The NE-trending transpressional faults are developed throughout the study area, some of which have controlled the early Paleozoic sedimentary and lithological patterns, such as the Tongren-Kaili fault and the Shiqian fault. The S-N-trending faults are compressional in nature, such as the Zunyi fault, and the E-W-trending ones, represented by the Zhenyuan fault, are sinistral strike-slip faults.

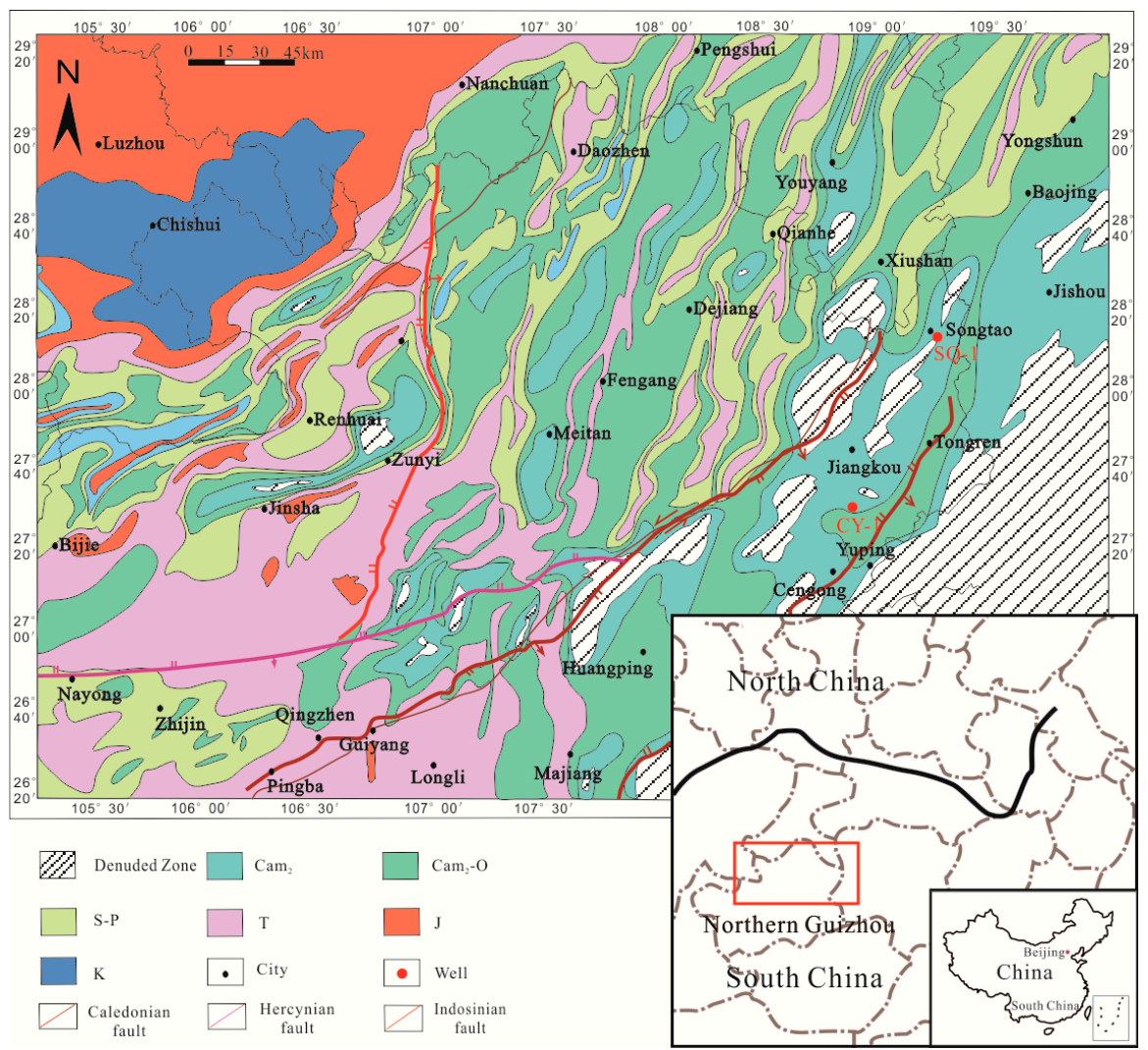

Figure 1. The simplified geologic map of the study area. Base map modified from [7]. 
The lithology of the Niutitang Formation is black carbonaceous mudstone, which gradually transitions from the Jiumenchong Formation. It gradually changes from carbonaceous mudstone $\rightarrow$ carbon-containing calcareous mudstone $\rightarrow$ calcareous mudstone $\rightarrow$ argillaceous limestone $\rightarrow$ argillaceous limestone. It has developed positive grain order structure and sand grain bedding, about $50-70 \mathrm{~m}$ thick. The Jiumenchong Formation is a gentle slope facies deposit, which gradually changes from micrite limestone $\rightarrow$ marlstone $\rightarrow$ calcareous mudstone $\rightarrow$ carbonaceous calcareous mudstone $\rightarrow$ carbonaceous mudstone. The Bianmachong Formation can be divided into three sections according to lithology. The first section is about 100-120 m thick, mainly black carbonaceous mudstone, with gray siltstone bands, and the mudstone has horizontal bedding, and the sandstone bedding and plastic deformation bedding are seen in the siltstone; the second section is about 120-150 m thick, the lithology is gray quartz powder-fine sandstone; the third section is about $30-50 \mathrm{~m}$ thick, the lithology is mainly black carbonaceous mudstone, carbonaceous mudstone, with horizontal bedding and pyrite.

\section{Samples and Methods}

\subsection{Samples}

In this study, core rocks of various depths obtained from CY-1 and SQ-1 were systematically collected as samples for analyzing TOC and geochemical element data. Among them, a total of 30 rock samples were collected in SQ-1 and 14 rock samples were collected in CY-1 according to the change of lithology. Based on the core description, the research samples were divided into siliceous rock, siltstone and shale. The siliceous rock showed a high degree of silica enrichment which was formed by biochemical action in the marine environment of the study area and input from high-silica debris. The siltstone is gray and fine-grained clastic rock deposited under certain hydrodynamic conditions. The shale is dark gray-black and fine-grained clastic rock with more clay minerals and obvious thin bedding structures. The samples collected in SQ-1 include: 23 shales, 6 siltstones, 1 siliceous rock; samples collected in CY-1 include: 13 shales, 1 siltstone. After the sampling was completed, the sample was stored in the sample bag to prevent it from being subject to external pollution. Figure 2 shows more detailed information of the research samples, including stratum, sample number, and core information.

\subsection{Methods}

All the studied cores were crushed to powdered samples and then analyzed to obtain the experimental data. An aliquot sample was treated with hydrochloric acid solution to dissolve the carbonate, and then rinsed with distilled water. After drying for several hours, the decarburized sample was analyzed using the LECO CS-400 analyzer for TOC analysis. To obtain the mineral composition, the studied samples were analyzed by Bruker D8 Discover X-ray diffractometer (XRD). The mineral identification and semi-quantitative results can be provided by diffraction result image through computer analysis. A wavelength-dispersive PHILIPS PW2404 X-ray fluorescence (XRF) spectrometer was used to measure the main elements on the glass disk following the typical procedure [8]. The PE NexION 350X inductively coupled plasma mass spectrometry (ICP-MS) was used for trace and rare earth elements analysis, the sample was placed in a closed high-pressure reaction furnace, and each sample was weighed and dissolved using mixed acid. 

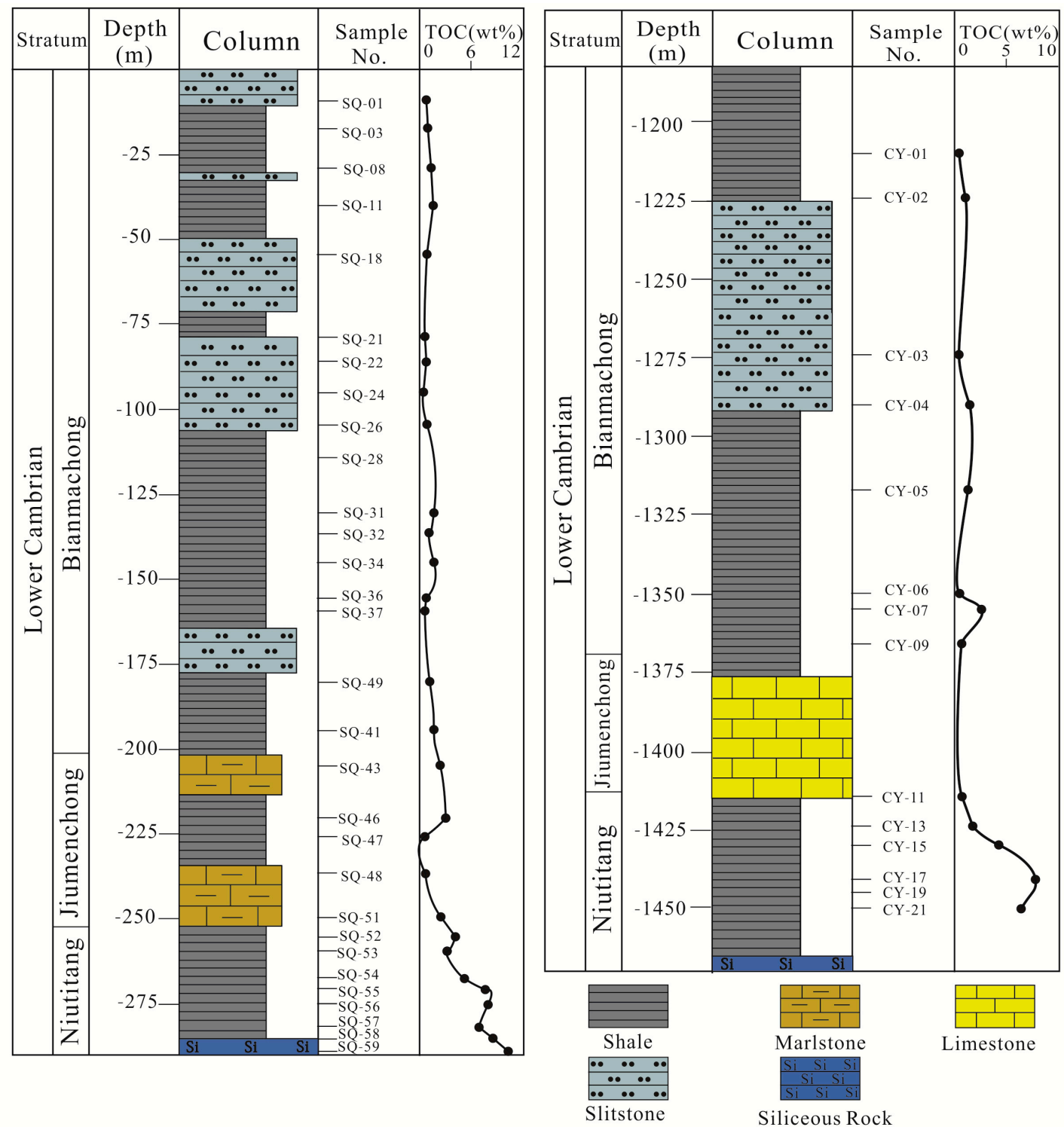

Figure 2. Stratigraphic column of the SQ-1 and CY-1. The left is SQ-1 and the right is CY-1.

\section{Results}

\subsection{Total Organic Carbon (TOC)}

The TOC data of all 30 samples in SQ-1 are listed in Figure 3, the TOC varies from $0.22 \mathrm{wt} . \%$ to $10.10 \mathrm{wt} . \%$ with an average of $2.60 \mathrm{wt} . \%$. According to the relationship between TOC and depth, it can be seen that there is a certain periodic change, and the significant characteristic of each period is the relatively high TOC value during that period. Overall, the maximum TOC is at the bottom of the Niutitang Formation. The TOC data of all 23 samples in CY- 1 are listed in Figure 4, and the TOC content varies from $0.23 \mathrm{wt} . \%$ to $7.7 \mathrm{wt} . \%$ with an average of $2.56 \mathrm{wt} . \%$. Its value also changes periodically with depth. The characteristics of each period are similar to those of SQ- 1 and the maximum TOC is at the bottom of the Niutitang Formation. 


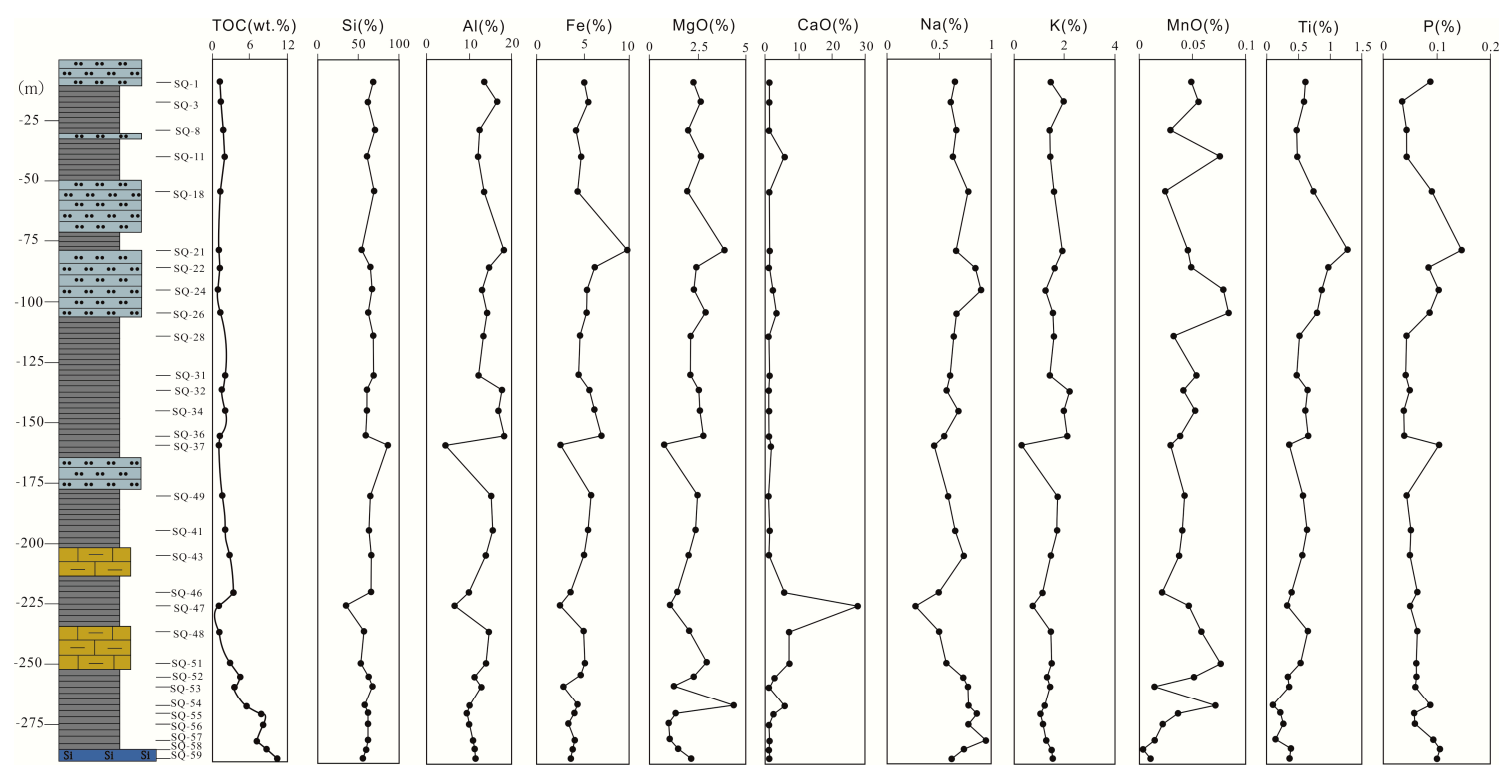

Figure 3. Vertical variation of major elements of the samples in SQ-1.

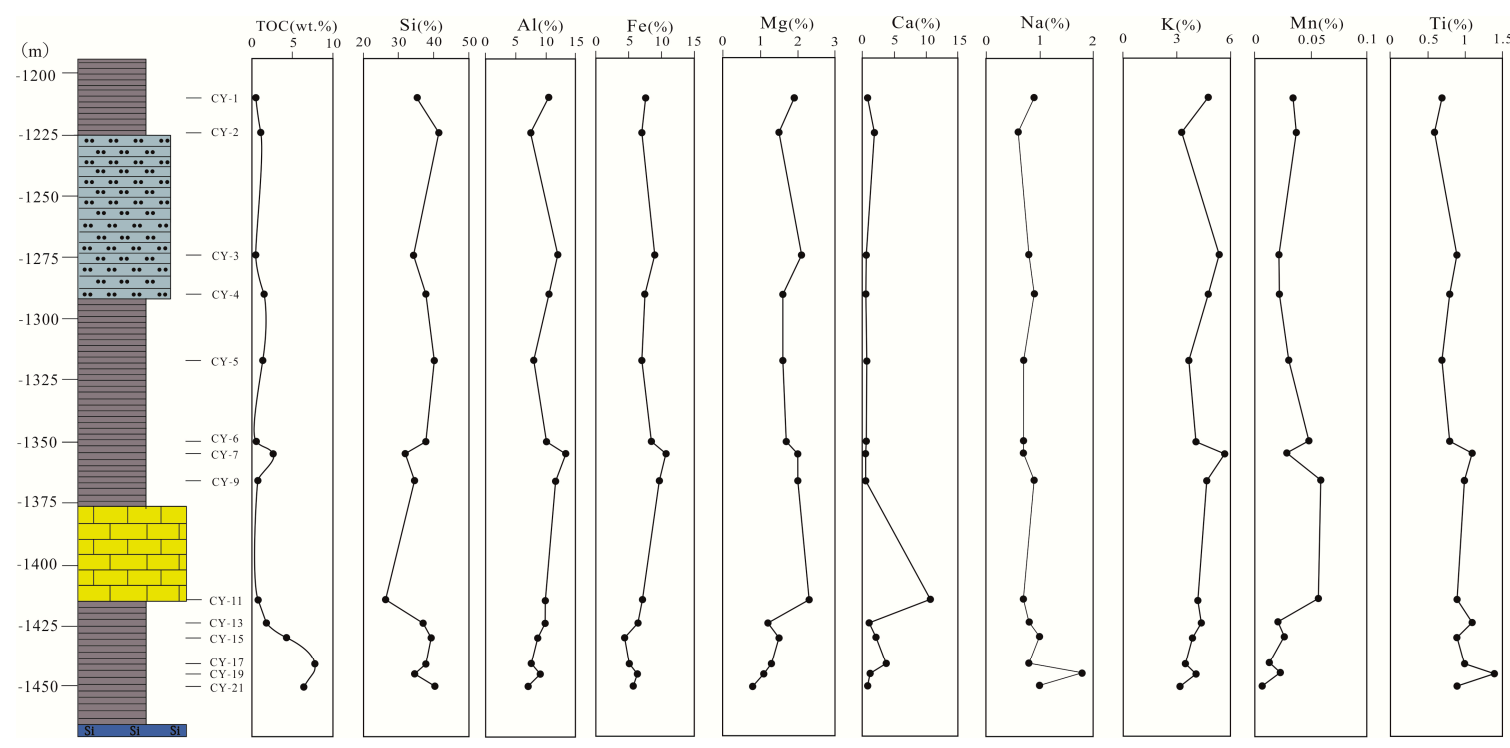

Figure 4. Vertical variation of major elements of the samples in CY-1.

\subsection{Main Elements}

The concentration of main elements or oxides in the SQ-1 samples is shown in Figure 3, including the average value and LOI (loss on ignition). The main elements or oxides are $\mathrm{Si}(62.84 \%), \mathrm{Al}(13.28 \%)$, $\mathrm{Fe}(5.16 \%), \mathrm{MgO}(2.15 \%), \mathrm{CaO}(2.80 \%), \mathrm{Na}(1.32 \%), \mathrm{K}(2.97 \%)$. The abundance of other main elements or oxides is obviously less than $1 \%$, including $\mathrm{MnO}(0.043 \%)$, Ti $(0.52 \%), \mathrm{P}(0.13 \%)$, etc. The concentration of the main elements or oxides in CY-1 samples is shown in Figure 4. The main elements are roughly the same as those in SQ-1, including $\mathrm{Si}(37.36 \%), \mathrm{Al}(8.73 \%), \mathrm{Fe}(6.43 \%)$ and $\mathrm{Mg}(1.45 \%), \mathrm{Ca}(2.50 \%)$, $\mathrm{K}(3.82 \%), \mathrm{Ti}(1.23 \%)$, and the abundance of the other elements is significantly less than 1 , including $\mathrm{Na}(0.88 \%), \mathrm{Mn}(0.026 \%)$, etc. The difference in the main elements between the two wells is mainly reflected in Figures 3 and 4. The content of Si and Al elements in SQ-1 is significantly greater than that in CY-1, and this indicates that the input of terrestrial detrital material during the deposition of SQ-1 is greater than that of CY-1 [9]. The enrichment of $\mathrm{Na}$ and Ti elements in $\mathrm{CY}-1$ is also different from that of SQ-1. 


\subsection{Trace Elements}

In the trace element data of core samples in SQ-1, the most abundant elements are $\mathrm{Ba}(4818.8 \mathrm{ppm})$, V (728.9 ppm), Sr (361.2 ppm), Zr (186.5 ppm), Rb (131.3 ppm), Cr (123.2 ppm), Ni (94.0 ppm), $\mathrm{Cu}(80.8 \mathrm{ppm})$, the other trace elements are less than $50 \mathrm{ppm}$. In the trace element data of core samples in CY-1, the most abundant elements are Ba (5862.8 ppm), V (438.7 ppm), Sr (321.1 ppm), Cr (134.4 ppm), $\mathrm{Ni}(118.0 \mathrm{ppm}), \mathrm{Zr}$ (163.09 ppm), Rb (112.4 ppm), Mo (71.6 ppm), Cu (80.6 ppm), the other trace element concentrations are less than $50 \mathrm{ppm}$.

Trace elements in rocks are usually composed of autogenous components and detrital components, and only autogenous components can be used as evidence of the evolution of the Earth's paleoenvironment [10]. Moreover, the rock composition is highly heterogeneous. If one only uses the concentration of trace elements lower or higher than the average shale value to determine its loss or enrichment (average shale, according to Wedepohl, 1971) [11], a certain deviation will occur. In order to rule out the influence of terrestrial detrital components on autogenous components, the $\mathrm{Al}$ element (mainly derived from terrigenous debris) that is stable during diagenesis is often used to standardize trace elements [12]. In order to make the standardized result easier to interpret, it is generally compared with the average shale value [13-15], expressed as an enrichment factor (EF) [13,14], and its calculation formula is as follows:

$$
\mathrm{EF}_{\mathrm{X}}=(\mathrm{X} / \mathrm{Al})_{\text {sample }} /(\mathrm{X} / \mathrm{Al})_{\text {average shale }}
$$

When $\mathrm{EF}_{\mathrm{X}}>1$, it means that element $\mathrm{X}$ or its oxide is enriched relative to the average shale (data from [11]); when $E F_{X}<1$, it means that element $X$ or its oxide is deficient relative to the average shale [12]. The results of EF value of SQ-1 and CY-1 are showed in Figure 5. The figure shows that elements $\mathrm{V}, \mathrm{Cr}, \mathrm{Ni}, \mathrm{Cu}, \mathrm{Sr}, \mathrm{Mo}$, and $\mathrm{Ba}$ are all enriched in varying degrees, while the elements of $\mathrm{Sc}, \mathrm{Co}$, $\mathrm{Ga}, \mathrm{Rb}, \mathrm{Cs}$, Th, U elements have a certain degree of loss in SQ-1. And in CY-1, the elements of Sc, V, Cr, $\mathrm{Ni}, \mathrm{Cu}, \mathrm{Mo}, \mathrm{Cs}$, and $\mathrm{Ba}$ are enriched to varying degrees, while the elements of $\mathrm{Co}, \mathrm{Ga}, \mathrm{Rb}, \mathrm{Sr}$, $\mathrm{Th}$, and $\mathrm{U}$ have a certain degree of loss.

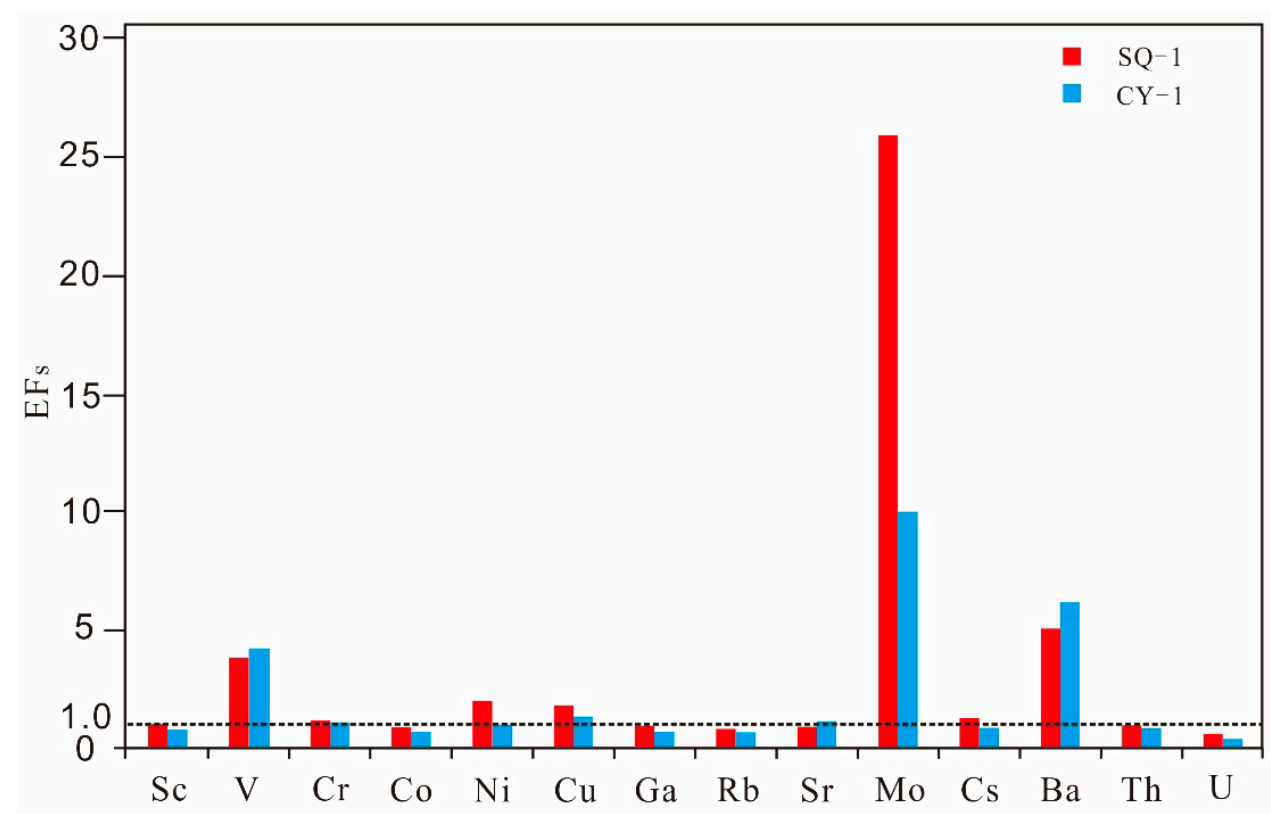

Figure 5. Enrichment factors (EFs) diagram of the selected trace elements of samples from SQ-1 and CY-1. 


\subsection{Rare Earth Elements (REE)}

The total REE concentration of the samples in SQ-1 ranged from 63.95 to 315.64 ppm, with an average of $182.54 \mathrm{ppm}$, which is closer to the Post-Archean Average Australian Shale (PAAS, 183.03 ppm) [16], slightly higher than the North American Shale composite (NASC, 173.21 ppm) [17], and significantly higher than the total rare earth element value of the upper continental crust (UCC, $146 \mathrm{ppm}$ ) [16]. The total REE concentration of the sample series in CY-1 ranged from 149.15 to $229.60 \mathrm{ppm}$, with an average of $184.49 \mathrm{ppm}$. It is also close to the Post-Archean Average Australian Shale (PAAS, 183.03 ppm) [16], slightly higher than the North American shale composite (NASC, $173.21 \mathrm{ppm}$ ) [17], and significantly higher than the total rare earth element value of the upper continental crust (UCC, 146 ppm) [16].

Figure 6 shows the NASC normalized REE distribution patterns of SQ-1 and CY-1. The REE distribution patterns in the two wells have a certain similarity, which is characterized by the light REE (LREE, from La to Eu) curve showing a certain volatility, while the heavy REE (HREE, from Gd to Lu) curve is relatively flat and the volatility is not strong. The $\mathrm{Ce}, \mathrm{Er}$, and Dy elements in the samples from both wells showed the same slight negative anomalies (Among them, $\left(\mathrm{Ce} / \mathrm{Ce}{ }^{*}\right)_{N}=2 \operatorname{Pr}_{N} /\left(\operatorname{La}_{N}+\operatorname{Pr}_{N}\right)$, $\left(\mathrm{Ce} / \mathrm{Ce}^{*}\right)_{\mathrm{N}}$ of SQ-1 ranged from 0.89 to 0.99 , with an average value of $0.94 ;\left(\mathrm{Ce} / \mathrm{Ce}^{*}\right)_{\mathrm{N}}$ of $\mathrm{CY}-1 \mathrm{ranged}$ from 0.88 to 0.99, with an average value of 0.94), and the Eu element of two wells shows a significant positive anomaly $\left(\right.$ Among them, $\left(\mathrm{Eu} / \mathrm{Eu}^{*}\right)_{\mathrm{N}}$ of SQ-1 ranged from 0.76 to 1.26 , with an average value of $0.98 ;\left(\mathrm{Eu} / \mathrm{Eu}^{*}\right)_{\mathrm{N}}$ of $\mathrm{CY}-1$ ranged from 0.78 to 1.46 , with an average value of 1.07$)$. According to the NASC normalized distribution patterns of the two wells, the black shale series in northern Guizhou shows obvious characteristics of LREE enrichment and relative depletion of HREE, that is, the total content of LREE ( $\sum$ LREE) is significantly higher than that of HREE ( $\sum$ HREE), the ratio between the two (LREE/HREE) also conforms to the characteristics. The LREE/HREE value range of SQ-1 is 5.48 to 10.60, with an average value of 8.11; the LREE/HREE value range of CY-1 is 5.41 to 11.11, with an average value of 7.93. According to the NASC normalized REE distribution patterns of SQ-1 and CY-1, it can be seen that, except for the Eu element, the distribution of rare earth elements in SQ-1 and CY-1 is relatively uniform, which shows that SQ-1 and CY-1 in northern Guizhou are similar to the North American shale composite in their sedimentary debris input and may also be controlled by similar sedimentary environments.

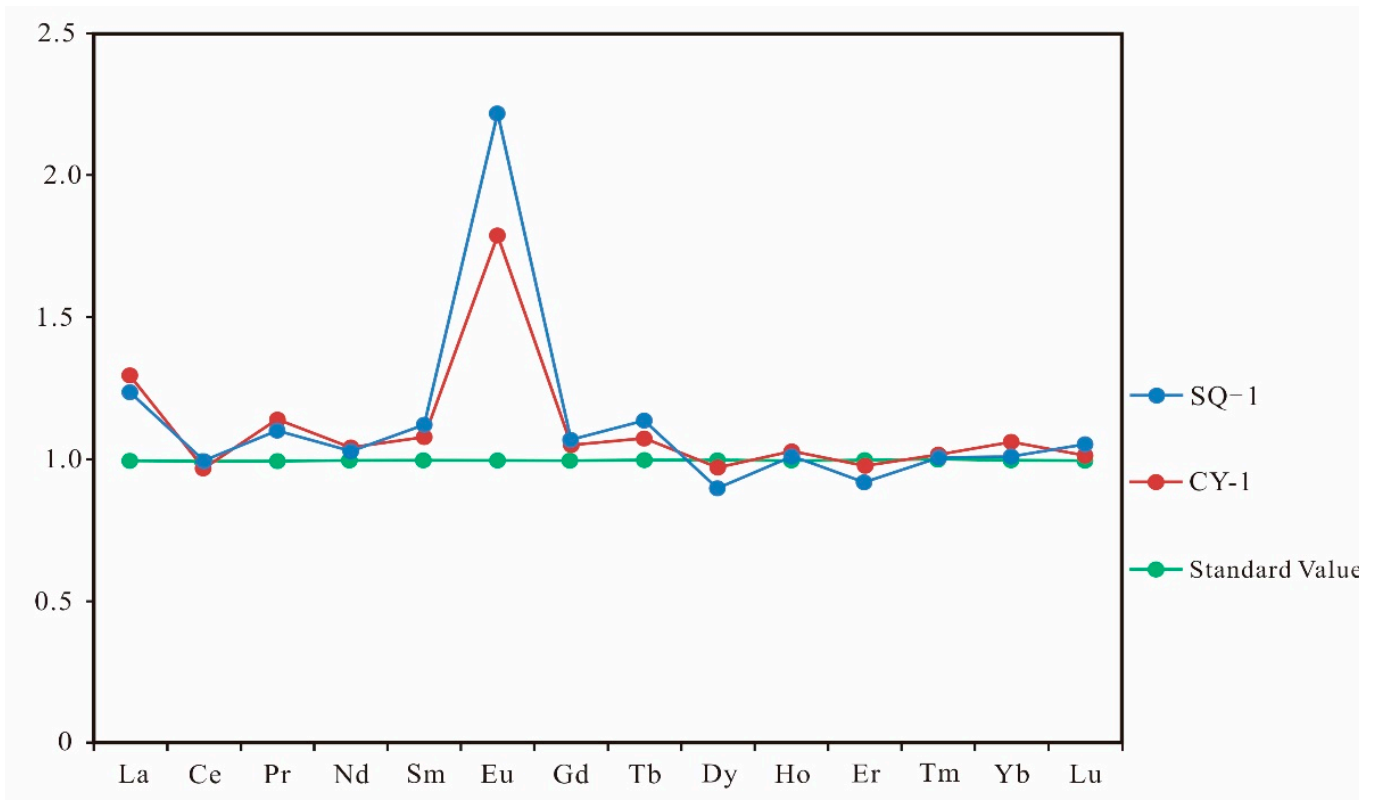

Figure 6. North American Shale composite (NASC)-normalized rare earth elements (REE) distribution patterns for the samples from SQ-1 and CY-1. 
The $(\mathrm{La} / \mathrm{Yb})_{\mathrm{N}}$ ratio has been widely used to characterize shale deposition rate [18-20]. The values of $(\mathrm{La} / \mathrm{Yb})_{\mathrm{N}}$ in the SQ-1 samples ranged from 0.82 to 1.67 , with an average value of 1.23 . The $(\mathrm{La} / \mathrm{Yb})_{\mathrm{N}}$ values in the CY-1 samples ranged from 0.68 to 1.58 , with an average value of 1.26 . The $(\mathrm{La} / \mathrm{Yb})_{\mathrm{N}} \mathrm{values}$ of the samples from the two wells indicate the high deposition rate of the black shale in the northern Guizhou area during the deposition process. The high deposition rate will lead to the relatively weak REE fractionation of different lithologies in the same stratum.

The core samples in SQ-1 and CY-1 show a certain degree of Ce anomaly and the average value of $\left(\mathrm{Ce} / \mathrm{Ce}^{*}\right)_{\mathrm{N}}$ is 0.94 . Since the $\left(\mathrm{Ce} / \mathrm{Ce}^{*}\right)_{\mathrm{N}}$ value does not change much in the vertical depth, it reflects that the Niutitang Formation and adjacent strata in this area exhibit weak heterogeneity during deposition. When sedimentation occurs in the ocean, the Ce anomaly in the sediment is easily affected by the La anomalous concentration, and most of the Ce negative anomalies are caused by the La positive anomaly in the sedimentary rock, so it is difficult to interpret the Ce anomaly. In this study, the La element of most samples also shows a certain negative anomaly. Combined with the intersection diagram of $\left(\mathrm{Ce} / \mathrm{Ce}^{*}\right)_{\mathrm{N}} /\left(\operatorname{Pr} / \mathrm{Pr}^{*}\right)_{\mathrm{N}}($ Figure 7$)$, most points fall in the IIIb area, reflecting that $\left(\mathrm{Ce} / \mathrm{Ce}^{*}\right)_{N}$ is caused by the actual negative Ce abnormalities.

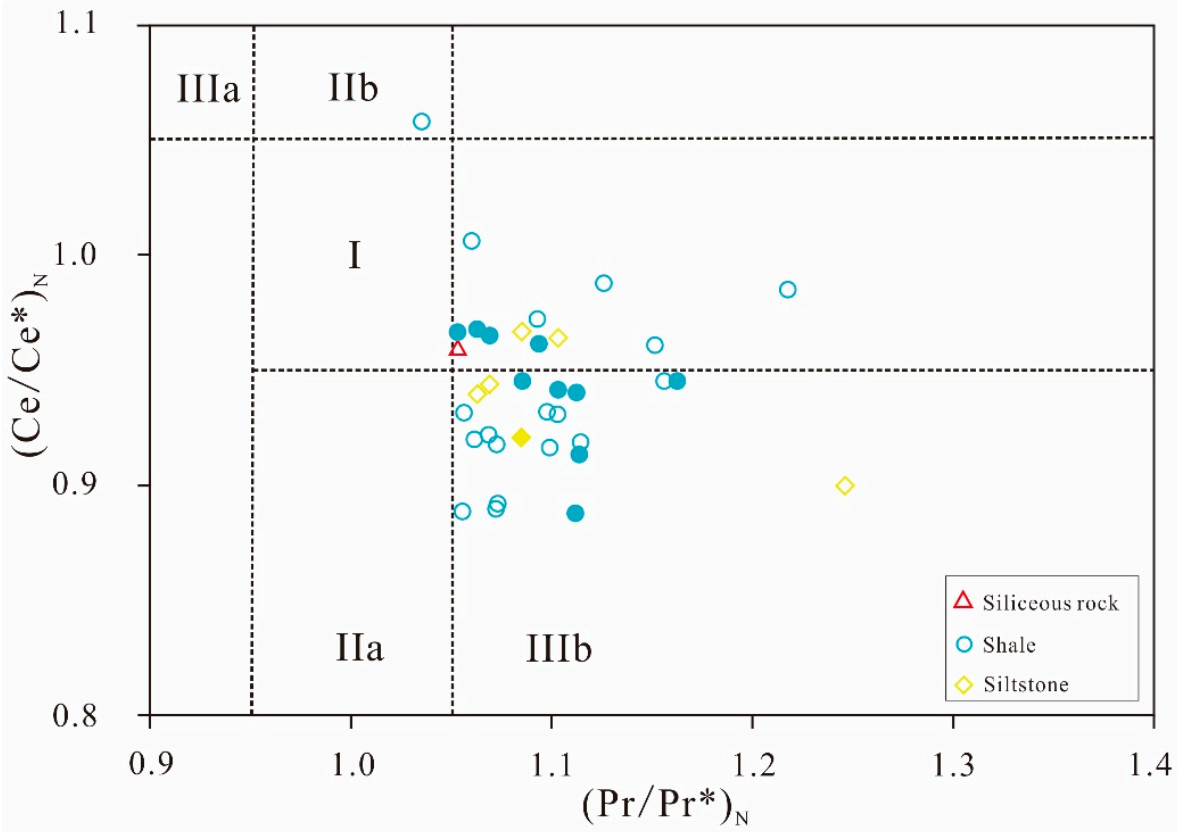

Figure 7. Cross plots demonstrating the relationship between $\mathrm{Pr} / \mathrm{Pr}^{*}$ against $\mathrm{Ce} / \mathrm{Ce}$ for SQ-1 (hollow points) and CY-1 (solid points). Base map modified from [21]. I: neither La anomaly nor Ce anomaly; IIa: positive La anomaly, no Ce anomaly; IIb: negative La anomaly, no Ce anomaly; IIIa: positive Ce anomaly; IIIb: negative Ce anomaly.

\subsection{Mineralogical Compositions}

According to X-ray diffraction (XRD) analysis of samples from two wells, the black shale series samples are mainly composed of clay minerals (chlorite, illite), quartz, feldspar (potassium feldspar, plagioclase), carbonate minerals (calcite, dolomite) and pyrite. The main characteristics of the samples from the two wells are the high content of quartz and clay minerals. Among them, the total amount of clay in the SQ-1 samples varied from $11 \%$ to $53 \%$, with an average of $31.87 \%$. Among the clay minerals, chlorite and smectite dominated. The quartz content varied from $32 \%$ to $84 \%$, with an average of $48.27 \%$. The content of feldspar varied from $4 \%$ to $24 \%$, with an average of $11.03 \%$, and potassium feldspar only appears at the bottom, and the other feldspar minerals are mainly plagioclase. The carbonate content varies from $0 \%$ to $38 \%$, with an average of $4.73 \%$. The samples of SQ-1 all contain a small amount of pyrite. The total amount of clay in the CY-1 samples varied from 19\% to 59\%, with an average of 36.21\%. 
Among clay minerals, chlorite and smectite dominated. The quartz content varied from $27 \%$ to $52 \%$, with an average of $46.07 \%$. The content of feldspar varied from $4 \%$ to $23 \%$, with an average of $8.86 \%$, and potash feldspar in SQ-1 also only appears at the bottom, and the other feldspar minerals are mainly plagioclase. The carbonate content varied from $0 \%$ to $32 \%$, with an average of $4.29 \%$. The samples of CY-1 all contain a small amount of pyrite. In general, the composition of clay minerals can represent the diagenetic transformation process from kaolinite to illite (I/S is an intermediate product) during the continuous compaction process, so the combination mode of clay minerals can reflect the diagenetic stage process. SQ-1 and CY-1 both showed higher illite content (the average content of SQ-1 was $62.3 \%$ and the average content of CY-1was $60.07 \%$ ) and lower I/S content (The average content of SQ-1 is $22.17 \%$ and the average content of CY-1 is $28.21 \%$ ), which indicated that the black shales of SQ-1 and CY-1 are in the late diagenetic stage [22].

\section{Discussion}

\subsection{Weathering Degree}

The chemical components in sedimentary rocks can usually represent certain mineralogical characteristics. In general, the content of chemical elements will be affected by the degree of chemical weathering [23]. Some cations with large ionic radius (such as $\mathrm{Al}, \mathrm{Mg}, \mathrm{Cs}$, etc.) can usually remain intact in sedimentary rocks more completely, while cations with small ionic radius (such as $\mathrm{K}, \mathrm{Na}, \mathrm{Ca}$, etc.) are easy to loss in the form of dissolved state during the weathering process [24,25]. The lost proportion of elements is proportional to the weathering degree [26].

For measuring the degree of weathering of rocks, the chemical index of alteration (CIA) and the chemical index of weathering (CIW) are commonly used. The definition formulas of CIA and CIW are as follows [24,27]:

$$
\begin{gathered}
\mathrm{CIA}=100 \times\left[\mathrm{Al}_{2} \mathrm{O}_{3} /\left(\mathrm{Al}_{2} \mathrm{O}_{3}+\mathrm{CaO}^{*}+\mathrm{Na}_{2} \mathrm{O}+\mathrm{K}_{2} \mathrm{O}\right)\right] \\
\mathrm{CIW}=100 \times\left[\mathrm{Al}_{2} \mathrm{O}_{3} /\left(\mathrm{Al}_{2} \mathrm{O}_{3}+\mathrm{CaO}^{*}+\mathrm{Na}_{2} \mathrm{O}\right)\right]
\end{gathered}
$$

The oxide unit in the above formula is mol, and $\mathrm{CaO}^{*}$ only refers to the amount of $\mathrm{CaO}$ derived from silicate minerals [24]. Under normal circumstances, it is necessary to calibrate the measured $\mathrm{CaO}$ content to confirm the presence of carbonate minerals. In this study, the measured $\mathrm{P}_{2} \mathrm{O}_{5}$ content was used to calibrate the $\mathrm{CaO}$ phosphate [28], namely:

$$
\mathrm{CaO}^{*}=\mathrm{CaO}-\mathrm{P}_{2} \mathrm{O}_{5} \times 10 / 3
$$

If the value obtained is less than the number of mol of $\mathrm{Na}_{2} \mathrm{O}$, the number of moles of $\mathrm{CaO}$ is regarded as the number of $\mathrm{mol}$ of $\mathrm{CaO}^{*}$. Otherwise, assume that the number of $\mathrm{mol}$ of $\mathrm{CaO}^{*}$ is equal to the number of mol of $\mathrm{Na}_{2} \mathrm{O}$ [28-31].

CIA and CIW are similar in calculation formulas, and both are used to judge the weathering intensity of protoliths during deposition. However, CIW does not count the K element in the calculation. This is to avoid the recirculation of $\mathrm{K}$ during the later diagenesis. Therefore, the formula of CIW makes it inapplicable to samples with high content of $\mathrm{K}$. The K element content of the research object in this article is less than or close to $5 \%$. In the data obtained from SQ- 1 and CY-1, all samples were mainly composed of clay minerals and quartz, so CIA and CIW could be used to characterize the degree of weathering in northern Guizhou. In SQ-1, except for the low CIA value of sample SQ-47, the CIA values of the other samples were between 58.48 and 80.67, with an average value of 70.71 . The CIA values of CY-1 were between 35.43 and 71.48, with an average value of 60.94. Compare the CIA data of the two wells with the Post-Archean Average Australian Shale (PAAS, CIA = 69, referred from [25]). This shows that the weathering degree of SQ-1 is higher than the average Archean shale, while the weathering degree of $\mathrm{CY}-1$ is lower than the average Archean shale.

Using the CIA and $\mathrm{Al} / \mathrm{Na}$ ratio to draw a cross plot (Figure 8), the samples of SQ-1 and CY-1 showed that the sediment source was weakly to moderately weathered, and most samples were 
revealed to be moderately weathered. Each sample not only showed a certain degree of differentiation on the CIA, but also reflected in the $\mathrm{Al} / \mathrm{Na}$ ratio. The $\mathrm{Al} / \mathrm{Na}$ ratio of each sample varied from 5.26 to 15.90. This phenomenon may be due to the exhaustion of sodium ions during diagenesis $[24,25]$.

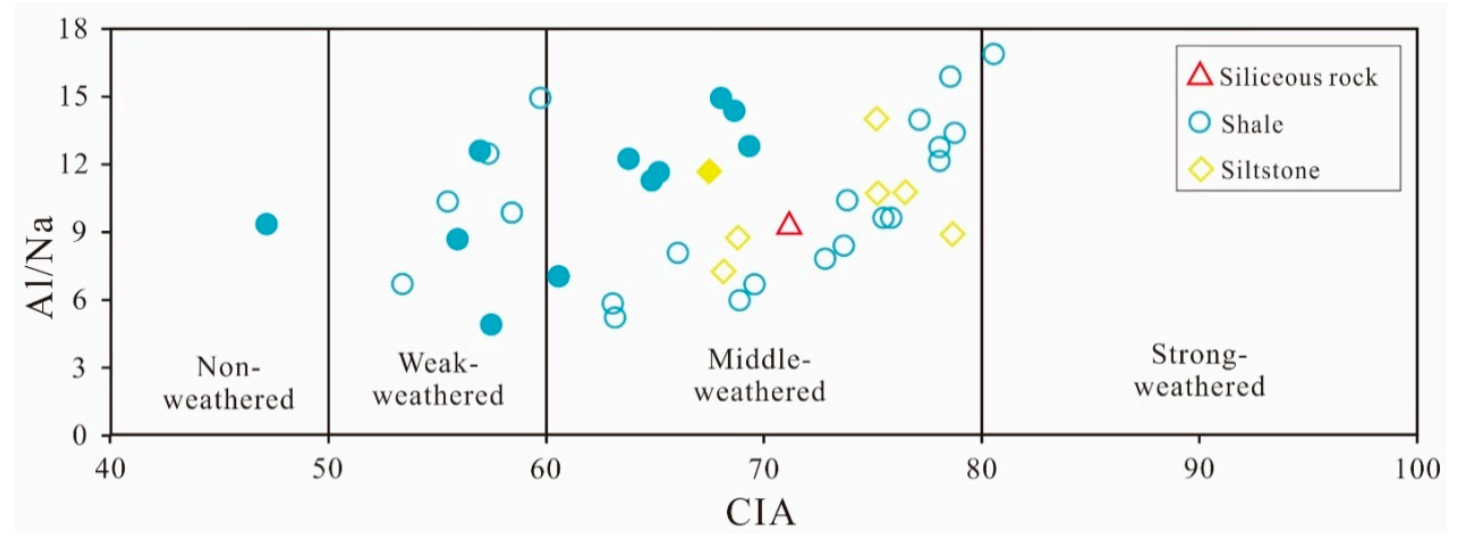

Figure 8. Cross plot of chemical index of alteration (CIA) values versus $\mathrm{Al} / \mathrm{Na}$ ratios demonstrating the weathering degree of sediment provenance. Hollow points are the samples from SQ- 1 and solid points are the samples from CY-1.

In addition, in SQ-1, except for the abnormally low CIW value of sample SQ-47, the CIW values of the other samples ranged from 60.74 to 92.57 , with an average of 79.51. In CY-1, except for the abnormally low CIW value of sample CY-11, the CIW value varied from 55.60 to 90.71 , with an average of 78.09. Therefore, both the CIA and CIW values show that the black shale series in SQ-1 and CY-1 may all originate from moderate weathering sources.

\subsection{Provenance}

Based on the experimental data in SQ-1 and CY-1, fixed element ratios (e.g., La/Sc, La/Co, Th/Sc, $\mathrm{Th} / \mathrm{Co}$ and $\mathrm{Cr} / \mathrm{Th}$ ) are calculated. Comparing the calculated data with the upper continental crust (UCC), lower continental crust (LCC) and oceanic crust (OC), it is believed that the black shale in northern Guizhou originated from the upper continental crust (UCC).

In general, the $(\mathrm{Gd} / \mathrm{Yb})_{\mathrm{N}}$ value in Post-Archean Formations is less than 2, while the $(\mathrm{Gd} / \mathrm{Yb})_{\mathrm{N}}$ value in other Archean Formations is greater than $2[16]$. The $(\mathrm{Gd} / \mathrm{Yb})_{\mathrm{N}}$ value of the samples in SQ-1 varied from 0.78 to 1.48 , with an average value of 1.06; the $(\mathrm{Gd} / \mathrm{Yb})_{\mathrm{N}}$ value of the samples in $\mathrm{CY}-1$ varied from 0.79 to 1.49 , with an average value of 1.00 . Therefore, the sediments provenance of the Niutitang, Jiumenchong and Bianmachong Formations in northern Guizhou area originated from the Post-Archean strata.

Some elements that will not migrate during the deposition process, such as $\mathrm{La}$, Th (representing felsic source rock) and Sc (representing iron-magnesia source rock). These elements usually show different chemical properties in iron-magnesia and felsic rocks. In geochemical indicators, the ratio of these elements (such as $\mathrm{La} / \mathrm{Sc}, \mathrm{La} / \mathrm{Co}, \mathrm{Th} / \mathrm{Sc}, \mathrm{Th} / \mathrm{Co}$, etc.) is often regarded as an important index parameter, and these index parameters are used to reflect information such as the source and composition of the rock [32,33], and these geochemical indicators are not affected by the deposition process [16]. These geochemical indicators have been widely used in many previous studies to distinguish felsic and iron-magnesia rocks [25,34]. According to the data, the geochemical index values of the black shales in SQ-1 and CY-1 are compared with felsic and iron-magnesia rocks respectively, their provenance characteristics are closer to felsic rocks.

In addition to the geochemical indicators mentioned above, there are some geochemical indicators (such as Th-Sc diagrams, $\mathrm{Co} / \mathrm{Th}-\mathrm{La} / \mathrm{Sc}$ diagrams) that can help visualize the source and composition of samples $[35,36]$. According to the Th-Sc diagram, SQ-1 and CY-1 are more of intermediate transition phase sources. Since the indicators in Table 1 only bisect the sources, the conclusion drawn by the Th-Sc 
diagram also has a certain reference significance, suggesting that there may be multiple sources of black shale in northern Guizhou area during the deposition process. Combined with the $\mathrm{Co} / \mathrm{Th}-\mathrm{La} / \mathrm{Sc}$ relationship diagram, it is shown that the $\mathrm{Co} / \mathrm{Th}-\mathrm{La} / \mathrm{Sc}$ characteristics of the samples are closer to that of felsic volcanic rocks, between andesite and felsic volcanic rocks (Figure 9).

Table 1. Range of several elemental ratios of the samples from the SQ-1 and CY-1 compared with the counterparts in sediments originated from the upper continental crust (UCC), lower continental crust (LCC), oceanic crust (OC), mafic rocks, and felsic rocks.

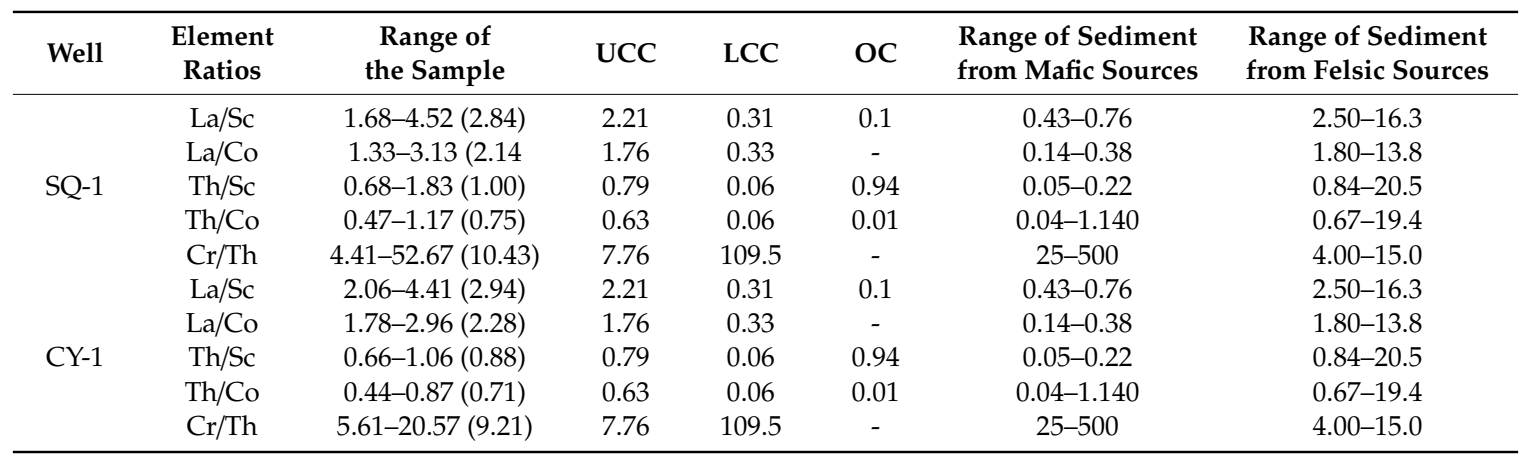

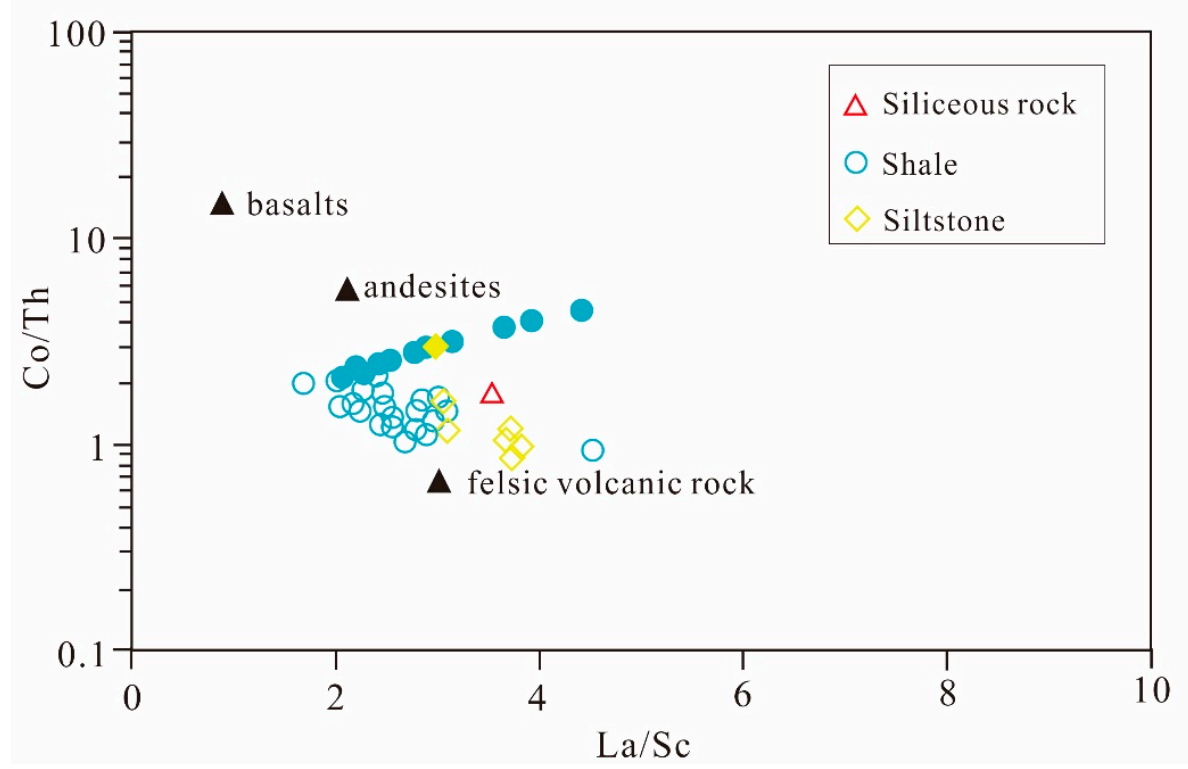

Figure 9. Source discrimination diagrams of $\mathrm{Co} / \mathrm{Th}$ vs. La/Sc. Hollow points are the samples from SQ-1 and solid points are the samples from CY-1.

In addition, the concentration of rare earth elements can also be used to infer the origin of fine-grained sedimentary rocks $[25,28]$. Previous studies have shown that felsic rocks usually exhibit higher LREE/HREE ratios, while mafic rocks have lower LREE/HREE ratios. The LREE/HREE ratio of SQ-1 varied from 5.48 to 10.60 , with an average of 8.11, and the LREE/HREE ratio of CY-1 varied from 5.42 to 10.62 , with an average of 7.93 , both of which are greater than the North American shale composite (NASC, 7.50). It can be clearly seen in the NASC normalized maps of SQ-1 and CY-1 that both wells have obvious positive anomalies in the Eu element. It is generally believed that the anomaly of Eu is inherited from the parent rock. Eu element is very rich in plagioclase, but relatively incompatible in other minerals. Considering the high LREE/HREE ratio and Eu anomaly in all samples, combined with Th-Sc diagram, it further shows that the sedimentary provenance in northern Guizhou area behave as felsic-mesophase provenance (Figure 10). 


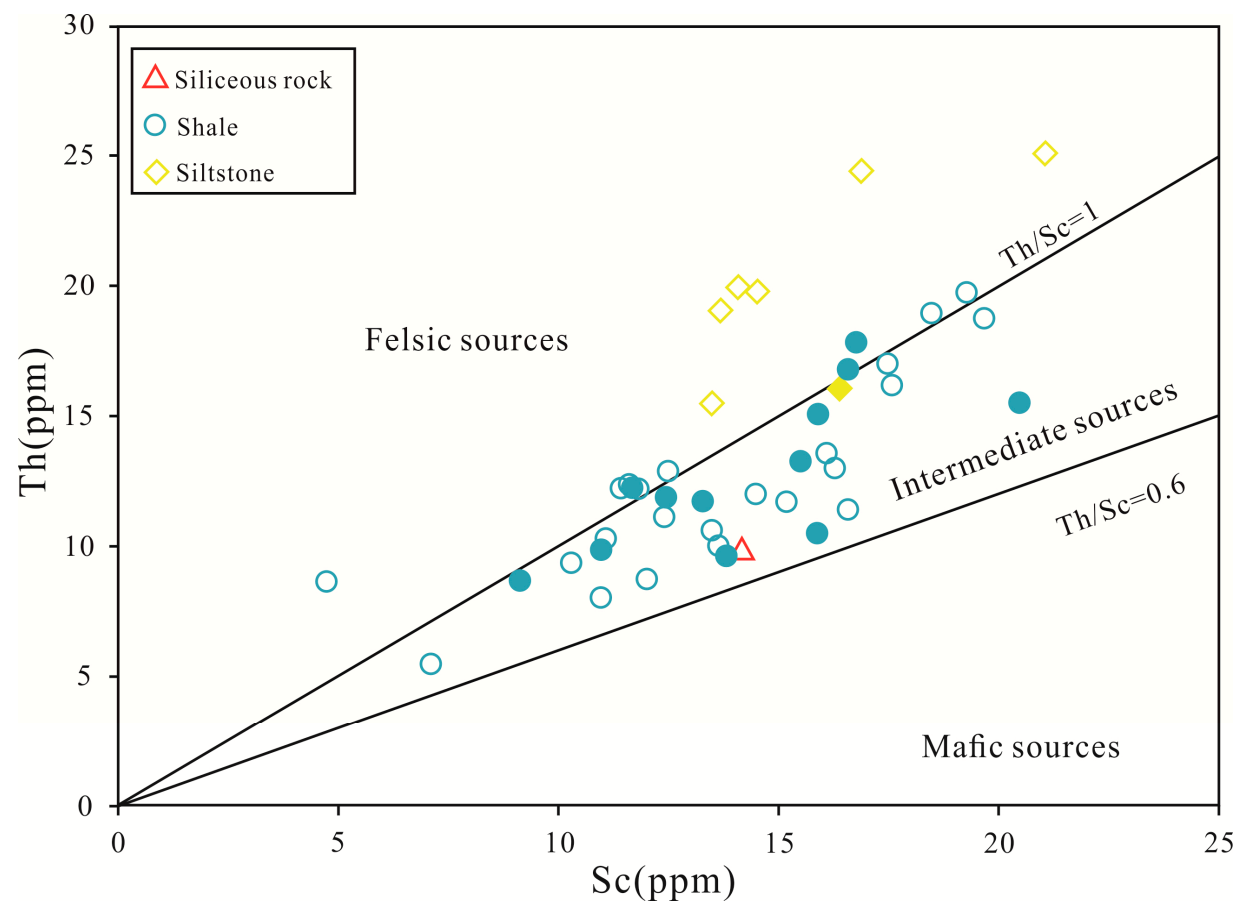

Figure 10. Source discrimination diagrams of Sc vs. Th. Hollow points are the samples from SQ-1 and solid points are the samples from CY-1.

In addition, La-Th-Sc and Th-Co-Z/10 ternary diagrams are used to explain the tectonic background of the Niutitang Formation and its adjacent strata in northern Guizhou (Figures 11 and 12). In the La-Th-Sc ternary diagram, the data of the samples investigated in SQ-1 and CY-1 are both located in the continental island arc area, while in the Th-Co-Zr/10 ternary chart, SQ- 1 and CY- 1 show high Co values, indicating that they are located on the margin of the passive continent. Combined with previous studies, considering that the sedimentary environment at that time was relatively stable, the northern Guizhou region transformed from the oceanic crust to the continental crust during the late Mesoproterozoic-Silurian period. The most sample data of SQ-1 and CY-1 fall on the passive continental margin in the Th-Co-Zr/10 ternary diagram. Each sample in the La-Th-Sc ternary diagram shows the characteristics of the continental island arc, combined with the Eu positive anomaly in the sample, which is considered to be the impact of the volcanic source material on the black shale during deposition.

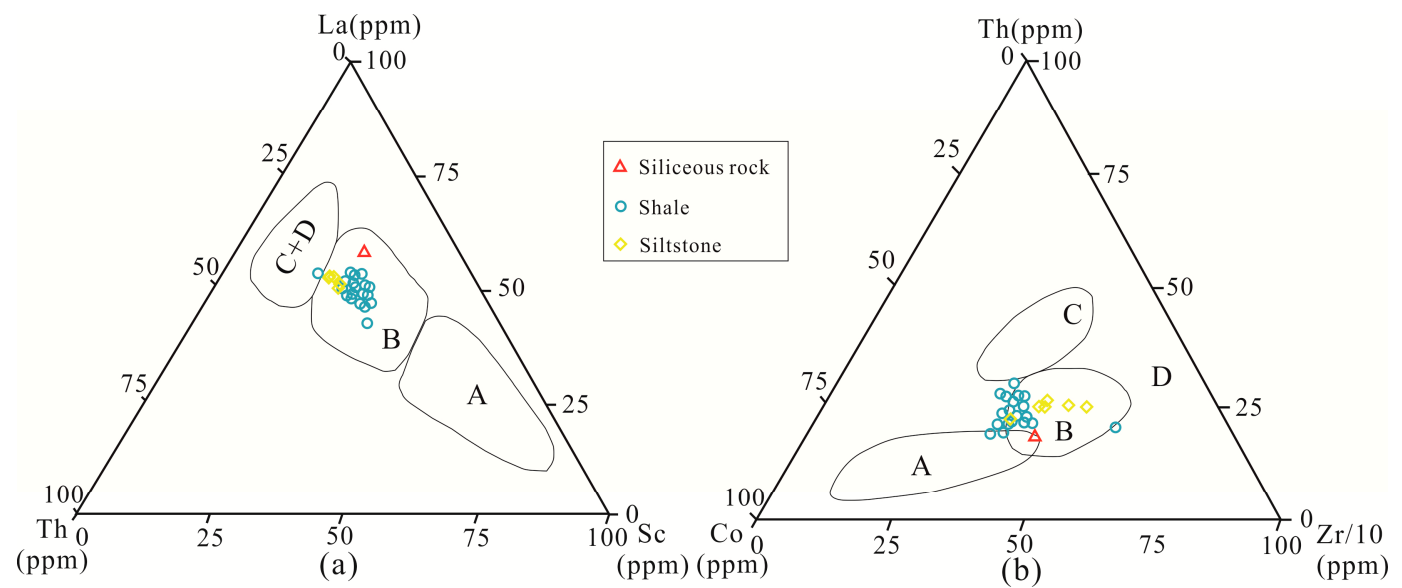

Figure 11. Tectonic setting discrimination diagrams of (a) La-Th-Sc and (b) Th-Co-Zr/10 for the samples from SQ-1. A: Oceanic island arc; B: Continental island arc; C: Active continental margin; D: Passive continental margin. Base map from [35]. 


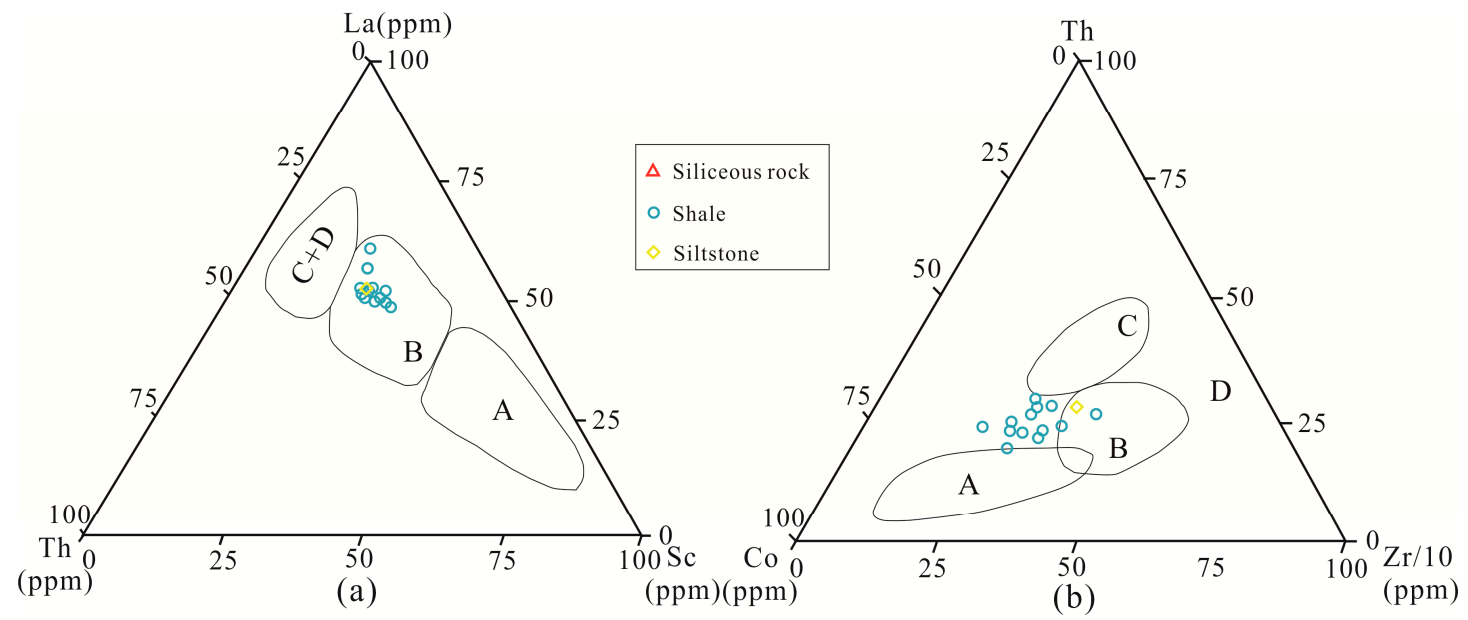

Figure 12. Tectonic setting discrimination diagrams of (a) La-Th-Sc and (b) Th-Co-Zr/10 for the samples from CY-1. A: Oceanic island arc; B: Continental island arc; C: Active continental margin; D: Passive continental margin. Base map from [35].

\subsection{Paleoredox Conditions}

During the deposition process, many trace elements (such as $\mathrm{U}, \mathrm{V}, \mathrm{Ni}$, etc.) are sensitive to the redox environment, and their ratios (such as $\mathrm{U} / \mathrm{Th}, \mathrm{V} / \mathrm{Cr}, \mathrm{Ni} / \mathrm{Co}$, and $\mathrm{V} /(\mathrm{V}+\mathrm{Ni}$ ) has been widely used as an indicator for the interpretation of the paleoredox environment $[14,15,37,38]$, and the value of these indicators decreases as the level of oxygen content in the water increases [15].The previous research has established and perfected the reference standards of $\mathrm{U} / \mathrm{Th}, \mathrm{V} / \mathrm{Cr}, \mathrm{Ni} / \mathrm{Co}$ and $\mathrm{V} /(\mathrm{V}+\mathrm{Ni})$, and established three categories of anoxic, dysoxic and oxic environment in each index [12,37,38].

In this study, it can be seen that the analysis of paleoredox conditions by the application indicators of the two wells showed good consistency; that is, the bottom of the Niutitang Formation showed anoxic environmental characteristics, while the top of the Niutitang Formation and Jiumenchong-Bianmachong Formation are characterized by gradually evolved into lean and oxidized sedimentary environment. Combined with the TOC curve, the collaborative analysis shows that the organic matter can be well preserved under the anoxic condition, the high value of the TOC can be preserved, and the poor oxygen or oxidation condition is not conducive to the preservation of the organic matter, and the TOC shows a relatively low value (Figures 13 and 14). The ranges of $\mathrm{U} / \mathrm{Th}, \mathrm{V} / \mathrm{Cr}, \mathrm{Ni} / \mathrm{Co}$ and $\mathrm{V} /(\mathrm{V}+\mathrm{Ni}$ ) of 30 samples in SQ-1 are, respectively, 0.19-6.71, 0.11-29.82, 1.78-31.41, 0.64-0.95, with average values of 1.84, 3.60, 5.39 , and 0.75 , respectively. The $\mathrm{U} / \mathrm{Th}, \mathrm{V} / \mathrm{Cr}, \mathrm{Ni} / \mathrm{Co}$ and $\mathrm{V} /(\mathrm{V}+\mathrm{Ni})$ ranges of 14 samples in $\mathrm{CY}-1$ are, respectively, $0.22-10.42,68-12.02,2.10-24.63,0.67-0.85$, with average values of $2.43,3.94,7.04$, and 0.76 , respectively. This information indicates that the Lower Cambrian black shale was deposited in the changing environment of anoxic-oxygen-poor-oxidation. It can be seen in Figures 13 and 14 that the $\mathrm{V} /(\mathrm{V}+\mathrm{Ni})$ curve is somewhat different from other curves. This difference might be related with some other than redox conditions factors like organic matter type, sediment accumulation rates, diagenetic and later mineralization processes, which can influence metal contents. At the same time, the slight anomalies of $\mathrm{Ce}\left(\left(\mathrm{Ce} / \mathrm{Ce}^{*}\right)_{\mathrm{N}}\right.$ is 0.93 in SQ-1 and CY-1) [39] and the cross graph of $\mathrm{EF}_{\mathrm{U}}$ and $\mathrm{EF}_{\mathrm{Mo}}$ can also support the above judgment (Figure 15) [40]. 


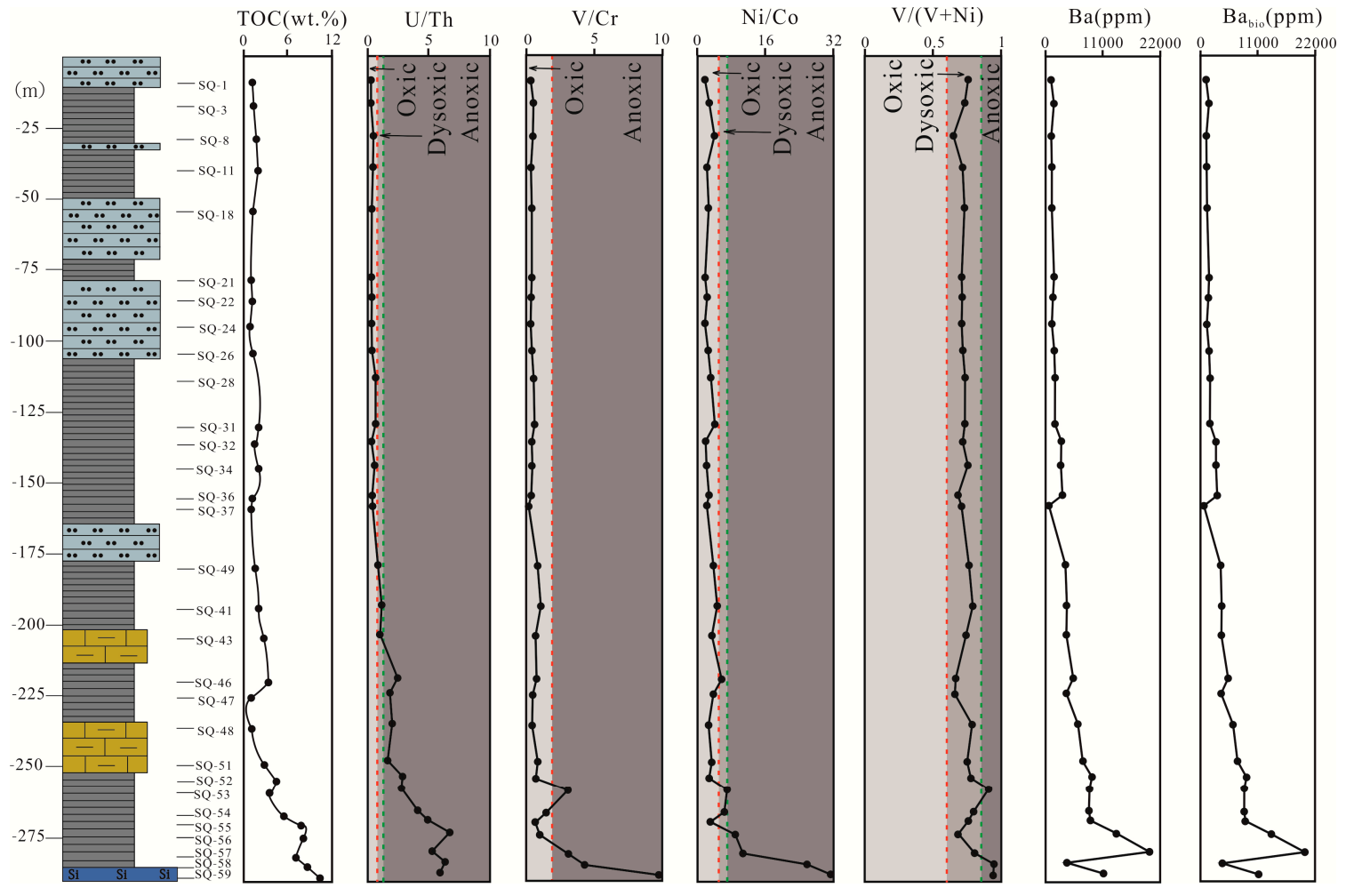

Figure 13. Stratigraphic profiles of SQ-1 for total organic carbon (TOC), U/Th, V/Cr, Ni/Co, V/(V + Ni), $\mathrm{Ba}$, and $\mathrm{Ba}_{\text {bio. }}$. The thresholds of $\mathrm{V} /(\mathrm{V}+\mathrm{Ni})(0.6,0.85)$ are referred from [37]; Redox thresholds of $\mathrm{U} / \mathrm{Th}$ $(0.75,1.25), \mathrm{V} / \mathrm{Cr}(2.0)$, and $\mathrm{Ni} / \mathrm{Co}(5.0,7.0)$ are referred from [38].


Figure 14. Stratigraphic profiles of $\mathrm{CY}-1$ for TOC, U/Th, V/Cr, Ni/Co, V/(V+Ni), Ba, and Babio. The thresholds of $\mathrm{V} /(\mathrm{V}+\mathrm{Ni})(0.6,0.85)$ are referred from [37]; Redox thresholds of $\mathrm{U} / \mathrm{Th}(0.75,1.25), \mathrm{V} / \mathrm{Cr}$ (2.0), and Ni/Co (5.0,7.0) are referred from [38]. 


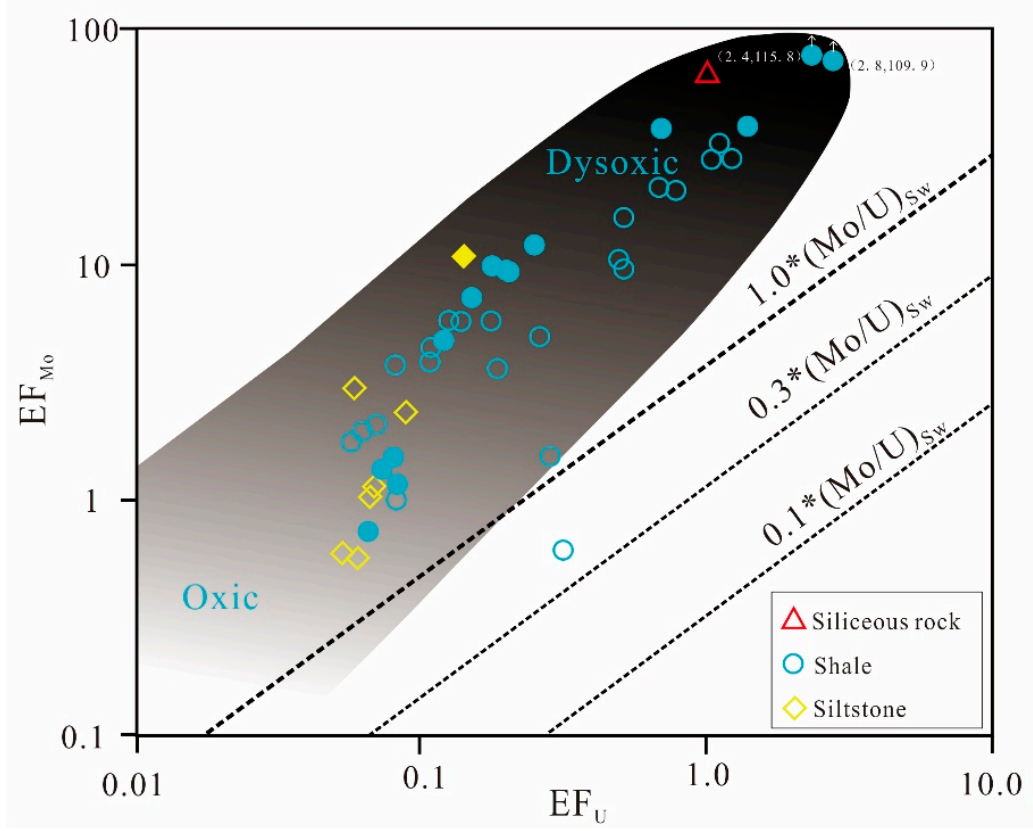

Figure 15. Cross plot of $\mathrm{EF}_{\mathrm{U}} \mathrm{vs}$. $\mathrm{EF}_{\mathrm{Mo}}$. The diagonal dashed lines represent $\mathrm{Mo} / \mathrm{U}$ molar ratios of the seawater (Sw). Hollow points are the samples from SQ-1 and solid points are the samples from CY-1.

\subsection{Paleoclimatic Conditions}

Previous studies have shown that the relative content and distribution of some main elements and trace elements in fine-grained rock can infer the paleoclimatic conditions at the time of deposition $[19,36,41,42]$. It has been agreed in previous studies that when deposition occurs under humid climate conditions [19,41,43], elements $\mathrm{Fe}, \mathrm{Mn}, \mathrm{V}, \mathrm{Cr}, \mathrm{Co}$, and $\mathrm{Ni}$ are relatively enriched in the sedimentary rock, and at the same time, the relatively fast evaporation rate under drought conditions will cause an increase in water alkalinity that causes precipitation of salt minerals, so $\mathrm{Ca}, \mathrm{Mg}, \mathrm{Na}, \mathrm{K}$, and $\mathrm{Sr}$ elements are easily enriched in sedimentary rocks.

Moreover, in addition to the above, element content can reflect the palaeoclimate in the process of fine-grained rock deposition to a certain extent, the ratio of some trace elements can also be used to characterize the palaeoclimate $[36,42,43]$, such as $\mathrm{Sr} / \mathrm{Cu}$ and $\mathrm{Ga} / \mathrm{Rb}$. Gallium (Ga) elements are mainly enriched in clay minerals, especially kaolinite, reflecting warm and humid climatic conditions [42,44]. Rubidium $(\mathrm{Rb})$ is closely related to illite, reflecting cold and arid climate conditions [42]. The colder and drier the climate at the time of deposition, the lower the $\mathrm{Ga} / \mathrm{Rb}$ ratio in the sedimentary rock. Usually under warm and humid paleoclimate conditions, the deposited fine-grained rocks usually exhibit low $\mathrm{Sr} / \mathrm{Cu}$ ratio and high $\mathrm{Ga} / \mathrm{Rb}$ ratio [36,41]. The $\mathrm{Sr} / \mathrm{Cu}$ ratio between 1.3-5.0 can indicate a warm and humid environment, while more than 5.0 represents hot and dry climatic conditions (Figure 16).

In this study, the $\mathrm{Sr} / \mathrm{Cu}$ value of SQ-1 varied between 0.32-18.13 (excluding the particularly high number SQ-47 sample) with an average of 3.62, and the $\mathrm{Ga} / \mathrm{Rb}$ ratio varying between $0.11-0.23$ with an average of 0.15 . Sr/Cu in CY-1 varying between $1.21-26.59$ with an average of 4.70 , and the $\mathrm{Ga} / \mathrm{Rb}$ ratio varied between $0.13-0.20$ with an average of 0.16 . Overall, these two indicators reflect the hot and humid climatic conditions of the Lower Cambrian period in northern Guizhou. 


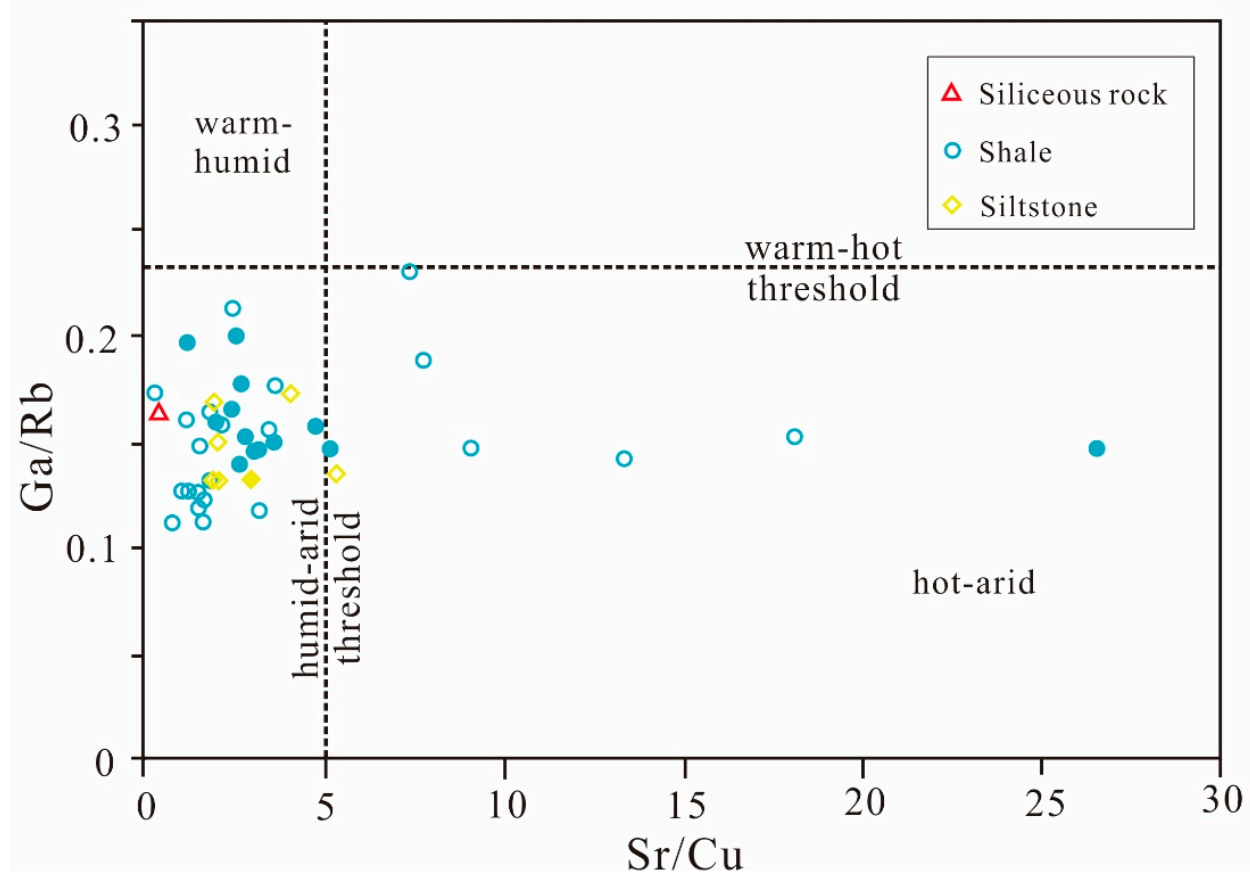

Figure 16. Cross plot of $\mathrm{Sr} / \mathrm{Cu}$ vs. $\mathrm{Ga} / \mathrm{Rb}$ ratios showing paleoclimatic conditions. Hollow points are the samples from SQ-1 and solid points are the samples from CY-1.

\subsection{Paleoproductivity}

During the process of sedimentation and burial, TOC is widely considered to be related to paleoproductivity $[45,46]$. Therefore, when used together with other indicators (such as Ba element), TOC content can often be used as an important indicator to measure paleoproductivity. It can be seen from the graphs of the relationship between TOC and depth in SQ-1 and CY-1 that TOC has a clear periodicity, and the TOC shows a periodic peak in each period with a distinctive feature. Ding et al. pointed out that the periodic peak of TOC appears in the middle of each cycle [10]. This phenomenon is explained by the fact that when the regional sea level rises, organic matter tends to accumulate, while when the regional sea level falls, organic matter tends to decompose (or deplete).

Biogenic barium $\left(\mathrm{Ba}_{\mathrm{bio}}\right)$ has been extensively used in analyzing the fluctuations of paleoproductivity in marine sediments [47,48]. Determining the Ba source is of great significance for applying $\mathrm{Ba}$ as a paleoproductivity indicator. Except for biogenic sources, there are many probably other sources contributing to Ba accumulation in marine sediments, namely: hydrothermal precipitates, detrital-aluminosilicates and benthic organisms secretion [48]. In this study, no relevant evidence has suggested that Ba originated from hydrothermal precipitates and benthic organisms secretion by far. A quite popular practice for distinguishing between biogenic and detrital barium is based on the following equation [48]:

$$
\mathrm{Ba}_{\text {bio }}=\mathrm{Ba}_{\text {Sampale }}-\left(\mathrm{Al} \times \mathrm{Ba} / \mathrm{Al}_{\mathrm{alu}}\right)=\mathrm{Ba}_{\text {Sampale }}-(\mathrm{Al} \times 0.0075)
$$

In the above equation, it is assumed that the source of all $\mathrm{Al}$ in the sediment sample is aluminosilicate, and $\mathrm{Ba} / \mathrm{Al}_{\mathrm{alu}}$ is calculated independently. Generally, $\mathrm{Ba} / \mathrm{Al}_{\text {alu }}$ is often replaced by the constant 0.0075 . As shown in Figures 13 and 14, the variation trends of $\mathrm{Ba}$ content and $\mathrm{Ba}_{\text {bio }}$ content in SQ-1 and CY-1 are highly similar, indicating that the Ba content in the sample is mainly derived from biological barium. Comparing the TOC and $\mathrm{Ba}_{\text {bio }}$ content figure, it is found that the shapes of the two figures are also consistent, but the TOC curve change lags the $\mathrm{Ba}_{\mathrm{bio}}$ curve change, the TOC high value point always closely follows the $\mathrm{Ba}_{\text {bio }}$ high value point, and the decrease of $\mathrm{Ba}_{\text {bio }}$ 
value also led to the decrease of the TOC value, indicating that paleoproductivity has a significant effect on the accumulation of organic matter, which largely determines the vertical change of TOC.

\subsection{Organic Matter Enrichment and Shale Gas Accumulation}

The accumulation mechanism of organic matter in modern and ancient sediments has been the focus of research and has been widely studied $[49,50]$. The surface productivity level and dissolved oxygen content are diverse in different depositional environments. These affect the sedimentation and deposition process, determine the mineral types and characteristics, and influence the organic matter abundance and other shale gas accumulation conditions. Many scholars have reached a consensus that the enrichment of organic matter requires favorable geological conditions, which are usually manifested in the following three aspects: non-oxidizing water environment $[49,51,52]$; relatively high primary productivity $[53,54]$; and appropriate deposition rate $[8,19,21,55]$. Based on the above analysis of the samples in the study area, it can be concluded that the Lower Cambrian black shale deposits in the northern Guizhou area are in a continuous change and relatively complex paleoenvironmental conditions, which is specifically manifested as receiving a source of moderate weathering (the CIA of samples from SQ-1 and CY-1 are mostly between 60-80) and undergoing continuously changing deposition environments from anoxic, dysoxic to oxic (among them, below SQ-53 in SQ-1, and below CY-11 inCY-1, U/Th $>0.75, \mathrm{~V} / \mathrm{Cr}>2.0, \mathrm{Ni} / \mathrm{Cu}>7.0$, this indicates that the water environment at the bottom of the two wells is anoxic), and the paleoclimatic conditions remain basically hot and humid. At the same time, this set of black shale also shows a high deposition rate.

Considering the aforementioned continuously changing deposition conditions, relatively high TOC content indicates relatively high paleoproductivity conditions at the time of deposition, the water redox environment determines the organic matter deposition and preservation process, and scholars generally believe that aerobic or oxygen-depleted conditions and arid to semi-arid conditions are not conducive to the accumulation and preservation of organic matter. At the same time, the relatively high deposition rate also has a very important effect on the preservation of organic matter. Firstly, a relatively high deposition rate will lead to the dispersion of organic matter. Secondly, under aerobic or oxygen-depleted conditions, a relatively high deposition rate will reduce the exposure time of organic matter in the aerobic bacteria degradation zone and reduce the decomposition consumption of organic matter $[8,56]$. In this case, the accumulation of organic matter will be largely constrained by paleoproductivity, and paleoproductivity determines the flux of organic matter during shale deposition and is the basis for organic matter enrichment. The similar longitudinal change trend between the paleoproductivity index $\mathrm{Ba}_{\mathrm{bio}}$ and the TOC content relationship diagram strongly validates this opinion (the average of $\mathrm{Ba}_{\text {bio }}$ at the bottom of SQ- 1 is about $11,500 \mathrm{ppm}$, and the TOC is about $8 \mathrm{wt} . \%$; the average of $\mathrm{Ba}_{\text {bio }}$ at the bottom of CY-1 is about $5500 \mathrm{ppm}$, and the TOC is about $6 \mathrm{wt} . \%$ ), further indicating that the accumulation of organic matter in this environment is mainly controlled by paleoproductivity.

The sedimentary water environment, paleoproductivity and sedimentation rate of the Niutitang Formation in northern Guizhou are all conducive to the enrichment of organic matter. The TOC data shows that the Niutitang Formation has good organic matter enrichment, but in actual production, the shale gas production potential in the Niutitang Formation is obviously inferior to that of the Longmaxi Formation in Sichuan Basin with similar organic matter enrichment. Due to the lack of vitrinite, the equivalent vitrinite reflectance of Niutitang and Longmaxi Formations is determined based on the bitumen reflectance conversion. The thermal evolution degree of organic matter in SQ-1 is in the range of $3.61-4.83 \%$, with an average value of $4.34 \%$, the TOC range is $0.22-10.10 \mathrm{wt} . \%$, with an average value of $2.60 \mathrm{wt} . \%$, and the thermal evolution degree of organic matter in CY- 1 is $2.68-4.04 \%$, with an average value of $3.51 \%$, and the TOC range is $0.23-10.40 \mathrm{wt} . \%$, with an average value of $3.10 \mathrm{wt} . \%$. In contrast, the thermal evolution degree of organic matter in the black shale samples of the well JY-1 in the Longmaxi Formation in the Sichuan Basin ranged from $2.20 \%$ to $3.13 \%$, with an average value of $2.65 \%$, and the TOC range was from 0.55 to $5.89 \mathrm{wt} . \%$, with an average value of $2.54 \mathrm{wt} . \%$ [5]. The above-mentioned static index data of organic matter show that the Niutitang Formation shale 
in the study area has the favorable parameter conditions for generating shale gas, but the actual gas content in the two sets of shale formations is quite different. A desorption analytical instrument was used to measure the shale gas content including the desorbed gas content $\left(\mathrm{V}_{\mathrm{d}}\right)$, residual gas content $\left(\mathrm{V}_{\mathrm{r}}\right)$ and lost gas content $\left(\mathrm{V}_{1}\right)$. The gas content of the organic-rich shale interval in the lower part of the JY-1 well was 1.52-8.85 $\mathrm{m}^{3} / \mathrm{t}$, with an average of $4.30 \mathrm{~m}^{3} / \mathrm{t}$, and had high gas abundance [5], while the gas content of SQ-1 was $0.05-2.39 \mathrm{~m}^{3} / \mathrm{t}$, with an average of $2.73 \mathrm{~m}^{3} / \mathrm{t}$, and the gas content of CY- 1 was $0.04-0.10 \mathrm{~m}^{3} / \mathrm{t}$, with an average of $0.073 \mathrm{~m}^{3} / \mathrm{t}$. Therefore, in addition to paying attention to the organic matter enrichment and evolution caused by initial deposition conditions, the constraints of shale gas production in the Niutitang Formation in northern Guizhou should also be evaluated for the reservoir preservation differences caused by later structural destruction.

\section{Conclusions}

This study is based on the sample geochemical data of SQ-1 and CY-1, combined with regional geological conditions analysis, which constrains the deposition conditions and organic matter enrichment of the Niutitang, Bianmachong and Jiumengchong shale formations in the northern Guizhou area of south China.

(1) The black shale series in northern Guizhou is a fine-grained rock deposited on the continental island arc as the tectonic background. Its sedimentary characteristics mainly include the supply of moderately weathered sources; the paleoclimatic conditions of deposition are mainly hot and humid, and have undergone a continuously changing deposition environments from anoxic, dysoxic to oxic and have a relatively high deposition rate.

(2) In sedimentary basins, paleoproductivity, redox conditions and deposition rate are the three major factors that affect the accumulation of organic matter. In the process of black shale deposition in northern Guizhou, paleoproductivity is obviously the main controlling factor for organic matter enrichment, and the redox conditions and deposition rate of the water environment play relatively weak roles in the deposition process.

(3) During the deposition of the Lower Cambrian black shale series in northern Guizhou, the water environment experienced a series of anoxic-dysoxic-oxic changes and, according to the paleoproductivity changes indicated by $\mathrm{Ba}_{\mathrm{bio}}$, the paleoproductivity changed from large to small. The combination of anaerobic water conditions, higher paleoproductivity and relatively fast sedimentation rate all result in the phenomenon of highly organic matter enrichment at the bottom of the Niutitang Formation. As the water conditions in the later period transition to an oxidizing environment and the paleoproductivity decreases, the organic matter enrichment degree gradually decreases.

(4) The static index parameters of organic matter in the Niutitang shale formation of northern Guizhou are favorable, and the organic matter enrichment conditions and thermal evolution degree are conducive to the shale gas generation. However, there is a big gap between the actual and expected gas content. The later tectonic evolution may cause shale gas loss due to the preservation condition transformations.

Author Contributions: Conceptualization, S.H. and Y.Z.; methodology, S.H. and Y.Z.; writing-original draft preparation, Y.Z. and S.H.; writing-review and editing, J.H., Y.R. and Z.T. All authors have read and agreed to the published version of the manuscript.

Funding: This research was supported by State Key Laboratory of Shale Oil and Gas Enrichment Mechanisms and Effective Development, National Natural Science Foundation of China (Grant no. 41802156), Fundamental Research Funds for the Central Universities (Grant no. 2020YQDC07).

Acknowledgments: Editors and anonymous reviewers are gratefully acknowledged.

Conflicts of Interest: The authors declare no conflict of interest. 


\section{References}

1. Zou, C.N. Unconventional Petroleum Geology; Geological Publishing House: Beijing, China, 2011; pp. 18-20. (In Chinese)

2. Zhang, J.C.; Jiang, S.L.; Tang, X.; Zhang, P.X.; Tang, Y.; Jin, T.Y. Accumulation types and resources characteristics of shale gas in China. Nat. Gas Ind. 2009, 29, 109-114. (In Chinese)

3. Zhang, J.C.; Yang, C.; Chen, Q.; Zhao, Q.R.; Wei, P.F.; Jiang, S.L. Deposition and distribution of potential shales in China. Earth Sci. Front. 2016, 23, 74-86. (In Chinese)

4. Zou, C.N.; Dong, D.Z.; Wang, S.J.; Li, J.Z.; Li, X.J.; Wang, Y.M.; Li, D.H.; Cheng, K.M. Geological characteristics, formation mechanism and resource potential of shale gas in China. Pet. Explor. Dev. 2010, 37, 641-653. (In Chinese) [CrossRef]

5. Guo, X.S. Rules of two-factor enrichment for marine shale gas in southern China-Understanding from the Longmaxi formation shale gas in Sichuan basin and its surrounding area. Acta Geol. Sin. 2014, 88, 1209-1218. (In Chinese)

6. Xia, W.; Yu, B.S.; Wang, Y.H.; Sun, M.D. Study on the depositional environment and organic accumulation mechanism in the Niutitang and Longmaxi formation, north Guizhou Province: A Case Study of well Renye 1 and well Xiye 1. J. Miner. Petrol. 2017, 37,77-89. (In Chinese)

7. Han, S.; Bai, S.; Tang, Z.; Rui, Y.; Gong, D.; Zhang, J. Nitrogen-rich gas shale logging evaluation and differential gas-bearing characterization of lower Cambrian formation in northern Guizhou, south China. Mar. Pet. Geol. 2020, 115, 104270. [CrossRef]

8. Goto, A.; Tatsumi, Y. Quantitative analysis of rock samples by an X-ray fluorescence spectrometer (I). Rigaku J. 1994, 11, 40-59.

9. Cao, J.; Yang, R.; Yin, W.; Hu, G.; Bian, L.; Fu, X. Mechanism of organic matter accumulation in residual bay environments: The early Cretaceous Qiangtang basin, Tibet. Energy Fuels 2018, 32, 1024-1037. [CrossRef]

10. Ding, J.; Zhang, J.; Tang, X.; Huo, Z.; Han, S.; Lang, Y.; Zheng, Y.; Li, X.; Liu, T. Elemental geochemical evidence for depositional conditions and organic matter enrichment of black rock series strata in an inter-platform basin: The lower Carboniferous Datang formation, southern Guizhou, southwest China. Minerals 2018, 8, 509. [CrossRef]

11. Wedepohl, K.H. Environmental influences on the chemical composition of shales and clays. Phys. Chem. Earth 1971, 8, 305-333. [CrossRef]

12. Tribovillard, N.; Algeo, T.J.; Lyons, T.; Riboulleau, A. Trace metals as paleoredox and paleoproductivity proxies: An update. Chem. Geol. 2006, 232, 12-32. [CrossRef]

13. Calvert, S.E.; Pedersen, T.F. Geochemistry of recent oxic and anoxic marine sediments: Implications for the geological record. Mar. Geol. 1993, 113, 67-88. [CrossRef]

14. Ross, D.J.K.; Bustin, R.M. Investigating the use of sedimentary geochemical proxies for paleoenvironment interpretation of thermally mature organic-rich strata: Examples from the Devonian-Mississippian shales, Western Canadian Sedimentary Basin. Chem. Geol. 2009, 260, 1-19. [CrossRef]

15. Rimmer, S.M. Geochemical paleoredox indicators in Devonian-Mississippian black shales, Central Appalachian Basin (USA). Chem. Geol. 2004, 206, 373-391. [CrossRef]

16. Taylor, S.R.; Mclennan, S.M. The Continental Crust: Its Composition and Evolution; Blackwell Scientific Publications: Hoboken, NJ, USA, 1985; p. 312.

17. Haskin, L.; Wildeman, T.; Haskin, M. An accurate procedure for the determination of the rare earths by neutron activation. J. Radioanal. Nucl. Chem. 1968, 1, 337-348. [CrossRef]

18. Wang, Z.; Fu, X.; Feng, X.; Song, C.; Wang, D.; Chen, W.; Zeng, S. Geochemical features of the black shales from the Wuyu Basin, southern Tibet: Implications for palaeoenvironment and palaeoclimate. Geol. J. 2017, 52, 282-297. [CrossRef]

19. Zhang, M.; Liu, Z.; Xu, S.; Sun, P.; Hu, X. Element response to the ancient lake information and its evolution history of argillaceous source rocks in the Lucaogou Formation in Sangonghe area of southern margin of Junggar Basin. J. Earth Sci. 2013, 24, 987-996. [CrossRef]

20. Zeng, S.; Wang, J.; Fu, X.; Chen, W.; Feng, X.; Wang, D.; Song, C.; Wang, Z.W. Geochemical characteristics, redox conditions, and organic matter accumulation of marine oil shale from the Changliang Mountain area, northern Tibet, China. Mar. Pet. Geol. 2015, 64, 203-221. [CrossRef] 
21. Eltom, H.A.; Abdullatif, O.M.; Makkawi, M.H.; Eltoum, I.-E.A. Rare earth element geochemistry of shallow carbonate outcropping strata in Saudi Arabia: Application for depositional environments prediction. Sediment. Geol. 2017, 348, 51-68. [CrossRef]

22. Yu, B.S.; Li, J.; Zeng, Q.N.; Sun, M.D.; Shi, M. Sedimentary Environment and Diagenesis of Rich Organic Shale; East China University of Technology Press: Shanghai, China, 2016; p. 125. (In Chinese)

23. Nesbitt, H.W.; Young, G.M. Prediction of some weathering trends of plutonic and volcanic rocks based on thermodynamic and kinetic considerations. Geochim. Cosmochim. Acta 1984, 48, 1523-1534. [CrossRef]

24. Nesbitt, H.W.; Young, G.M. Early Proterozoic climates and plate motions inferred from major element chemistry of lutites. Nature 1982, 299, 715-717. [CrossRef]

25. Kasanzu, C.; Maboko, M.A.; Manya, S. Geochemistry of fine-grained clastic sedimentary rocks of the Neoproterozoic Ikorongo Group, NE Tanzania: Implications for provenance and source rock weathering. Precambrian Res. 2008, 164, 201-213. [CrossRef]

26. Condie, K.C. Chemical composition and evolution of the upper continental crust: Contrasting results from surface samples and shales. Chem. Geol. 1993, 104,1-37. [CrossRef]

27. Harnois, L. The CIW index: A new chemical index of weathering. Sediment. Geol. 1988, 55, 319-322. [CrossRef]

28. Mclennan, S.M.; Hemming, S.; Mcdaniel, D.K.; Hanson, G.N. Geochemical approaches to sedimentation, provenance, and tectonics. Geol. Soc. Am. 1993, 284, 21-40.

29. Bock, B.; Mclennan, S.M.; Hanson, G.N. Geochemistry and provenance of the middle Ordovician Austin Glen Member (Normanskill Formation) and the Taconian orogeny in New England. Sedimentology 2010, 45, 635-655. [CrossRef]

30. Yan, D.; Chen, D.; Wang, Q.; Wang, J. Large-scale climatic fluctuations in the latest Ordovician on the Yangtze block, south China. Geology 2010, 38, 599-602. [CrossRef]

31. Tang, X.; Zhang, J.; Liu, Y.; Yang, C.; Chen, Q.; Dang, W.; Zhao, P. Geochemistry of organic matter and elements of black shale during weathering in Northern Guizhou, Southwestern China: Their mobilization and inter-connection. Geochemistry 2018, 78, 140-151. [CrossRef]

32. Cullers, R.L.; Podkovyrov, V.N. Geochemistry of the Mesoproterozoic Lakhanda shales in southeastern Yakutia, Russia: Implications for mineralogical and provenance control, and recycling. Precambrian Res. 2000, 104, 77-93. [CrossRef]

33. Nowrouzi, Z.; Moussavi-Harami, R.; Mahboubi, A.; Gharaie, M.H.M.; Ghaemi, F. Petrography and geochemistry of Silurian Niur sandstones, Derenjal Mountains, East Central Iran: Implications for tectonic setting, provenance and weathering. Arab. J. Geosci. 2014, 7, 2793-2813. [CrossRef]

34. Mclennan, S.M.; Nance, W.B.; Taylor, S.R. Rare earth element-thorium correlations in sedimentary rocks, and the composition of the continental crust. Geochim. Cosmochim. Acta 1980, 44, 1833-1839. [CrossRef]

35. Bhatia, M.R.; Crook, K.A.W. Trace element characteristics of graywackes and tectonic setting discrimination of sedimentary basins. Contrib. Miner. Pet. 1986, 92, 181-193. [CrossRef]

36. Xie, G.; Shen, Y.; Liu, S.; Hao, W. Trace and rare earth element (REE) characteristics of mudstones from Eocene Pinghu Formation and Oligocene Huagang Formation in Xihu Sag, East China Sea Basin: Implications for provenance, depositional conditions and paleoclimate. Mar. Petrol. Geol. 2018, 92, 20-36. [CrossRef]

37. Hatch, J.R.; Leventhal, J.S. Relationship between inferred redox potential of the depositional environment and geochemistry of the upper Pennsylvanian (Missourian) stark shale member of the Dennis Limestone, Wabaunsee County, Kansas, USA. Chem. Geol. 1992, 99, 65-82. [CrossRef]

38. Jones, B.; Manning, D. Comparison of geochemical indices used for the interpretation of palaeoredox conditions in ancient mudstones. Chem. Geol. 1994, 111, 111-129. [CrossRef]

39. Shields-Zhou, G.; Stille, P. Diagenetic constraints on the use of cerium anomalies as palaeoseawater redox proxies: An isotopic and REE study of Cambrian phosphorites. Chem. Geol. 2001, 175, 29-48. [CrossRef]

40. Zhou, L.; Algeo, T.J.; Shen, J.; Hu, Z.; Gong, H.; Xie, S.; Huang, J.; Gao, S. Changes in marine productivity and redox conditions during the Late Ordovician Hirnantian glaciation. Palaeogeogr. Palaeoclim. Palaeoecol. 2015, 420, 223-234. [CrossRef]

41. Cao, J.; Wu, M.; Chen, Y.; Hu, K.; Bian, L.; Wang, L.; Zhang, Y. Trace and rare earth element geochemistry of Jurassic mudstones in the northern Qaidam Basin, northwest China. Chem. Erde-Geochem. 2012, 72, $245-252$. [CrossRef] 
42. Roy, D.K.; Roser, B.P. Climatic control on the composition of Carboniferous-Permian Gondwana sediments, Khalaspir basin, Bangladesh. Gondwana Res. 2013, 23, 1163-1171. [CrossRef]

43. Yandoka, B.M.S.; Wan, H.A.; Abubakar, M.B.; Hakimi, M.H.; Adegoke, A.K. Geochemical characterisation of Early Cretaceous lacustrine sediments of Bima Formation, Yola Sub-basin, Northern Benue Trough, NE Nigeria: Organic matter input, preservation, paleoenvironment and palaeoclimatic conditions. Mar. Pet. Geol. 2015, 61, 82-94. [CrossRef]

44. Beckmann, B.; Flögel, S.; Hofmann, P.; Schulz, M.; Wagner, T. Orbital forcing of Cretaceous river discharge in tropical Africa and ocean response. Nature 2005, 437, 241-244. [CrossRef] [PubMed]

45. Wei, H.; Chen, D.; Wang, J.; Yu, H.; Tucker, M. Organic accumulation in the lower Chihsia Formation (Middle Permian) of South China: Constraints from pyrite morphology and multiple geochemical proxies. Palaeogeogr. Palaeoclim. Palaeoecol. 2012, 353, 73-86. [CrossRef]

46. Nara, F.; Tani, Y.; Soma, Y.; Soma, M.; Naraoka, H.; Watanabe, T.; Horiuchi, K.; Kawai, T.; Oda, T.; Nakamura, T. Response of phytoplankton productivity to climate change recorded by sedimentary photosynthetic pigments in Lake Hovsgol (Mongolia) for the last 23,000 years. Quat. Int. 2005, 136, 71-81. [CrossRef]

47. Francois, R.; Honjo, S.; Manganini, S.J.; Ravizza, G.E. Biogenic barium fluxes to the deep sea: Implications for paleoproductivity reconstruction. Glob. Biogeochem. Cycles 1995, 9, 289-303. [CrossRef]

48. Dymond, J.; Suess, E.; Lyle, M. Barium in deep-sea sediment: A geochemical proxy for paleoproductivity. Paleoceanography 1992, 7, 163-181. [CrossRef]

49. Demaison, G.J.; Moore, G.T. Anoxic environments and oil source bed genesis. AAPG Bull. 1980, 64, 1179-1209. [CrossRef]

50. Murphy, A.E.; Sageman, B.B.; Hollander, D.J.; Lyons, T.W.; Brett, C.E. Black shale deposition and faunal overturn in the Devonian Appalachian Basin: Clastic starvation, seasonal water-column mixing, and efficient biolimiting nutrient recycling. Paleoceanography 2000, 15, 280-291. [CrossRef]

51. Arthur, M.A.; Sageman, B.B. Marine black shales: Depositional mechanisms and environments of ancient deposits. Ann. Rev. Earth Planet. Sci. 1994, 22, 499-551. [CrossRef]

52. Mort, H.; Jacquat, O.; Adatte, T.; Steinmann, P.; Föllmi, K.; Matera, V.; Berner, Z.; Stüben, D. The Cenomanian/ Turonian anoxic event at the Bonarelli Level in Italy and Spain: Enhanced productivity and/or better preservation? Cretac. Res. 2007, 28, 597-612. [CrossRef]

53. Pedersen, T.F.; Calvert, S.E. Anoxia vs. productivity: What controls the formation of organic-carbon-rich sediments and sedimentary rocks? AAPG Bull. 1990, 74, 454-466.

54. Gallego-Torres, D.; Martínez-Ruiz, F.; Paytan, A.; Jiménez-Espejo, F.; Ortega-Huertas, M. Pliocene-Holocene evolution of depositional conditions in the eastern Mediterranean: Role of anoxia vs. productivity at time of sapropel deposition. Palaeogeogr. Palaeoclim. Palaeoecol. 2007, 246, 424-439. [CrossRef]

55. Tyson, R.V. The "productivity versus preservation" controversy: Cause, flaws, and resolution. Soc. Sediment. Geol. 2005, 82, 17-33.

56. Ibach, L.E.J. Relationship between sedimentation rate and total organic carbon content in ancient marine sediments. AAPG Bull. 1982, 66, 170-183.

(C) 2020 by the authors. Licensee MDPI, Basel, Switzerland. This article is an open access article distributed under the terms and conditions of the Creative Commons Attribution (CC BY) license (http://creativecommons.org/licenses/by/4.0/). 